\title{
Current Status of Environmental, Health, and Safet Issues of Lithium Polymer Electric Vehicle Batteries
}

David Corbus and Carol J. Hammel

National Renewable Energy Laboratory 1617 Cole Boulevard Golden, Colorado 80401-3393

A national laboratory of the U.S. Department of Energy Managed by Midwest Research Institute under Contract No. DE-AC36-83CH10093

Prepared under Task No. AS015440

February 1995 


\section{NOTICE}

This report was prepared as an account of work sponsored by an agency of the United States government. Neither the United States government nor any agency thereof, nor any of their employees, makes any warranty, express or implied, or assumes any legal liability or responsibility for the accuracy, completeness, or usefulness of any information, apparatus, product, or process disclosed, or represents that its use would not infringe privately owned rights. Reference herein to any specific commercial product, process, or service by trade name, trademark, manufacturer, or otherwise does not necessarily constitute or imply its endorsement, recommendation, or favoring by the United States government or any agency thereof. The views and opinions of authors expressed herein do not necessarily state or reflect those of the United States government or any agency thereof.

Available to DOE and DOE contractors from:

Office of Scientific and Technical Information (OSTI)

P.O. Box 62

Oak Ridge, TN 37831

Prices available by calling (615) 576-8401

Available to the public from:

National Technical Information Service (NTIS)

U.S. Department of Commerce

5285 Port Royal Road

Springfield, VA 22161

(703) $487-4650$ 


\section{Preface}

Recent advances in the development of lithium solid polymer electrolyte (SPE) batteries have resulted in an interest in utilizing this technology for propulsion in electric vehicles (EVs). An important part of the commercialization of any technology is an assessment of environmental, health, and safety (EH\&S) issues. This report examines the potential EH\&S issues associated with the use of the lithium SPE battery technology as the energy source in EVs.

The Analytic Studies Division prepared this report for the Electric and Hybrid Propulsion Division of the Office of Transportation Technologies in the U.S. Department of Energy (DOE). The report is intended to help DOE determine the direction of its research, development, and demonstration program for lithium SPE technology, and it is one part of DOE's program to work with industry to commercialize lithium SPE batteries for EVs. Previous EH\&S reports were prepared by the Analytic Studies Division for sodium-sulfur and nickel metal-hydride EV batteries. As the assessment of EH\&S issues for advanced EV batteries is an ongoing task, future studies will build on the analysis contained in this report and previous reports.

We are indebted to many people who helped us obtain information for this report. We thank Rudy Jungst of Sandia National Laboratories for helping us to understand some of the recycling and reclamation aspects of lithium SPE batteries. We also thank Joe Sabatini of A.D. Little Inc., who supplied information on the toxicity of lithium battery constituents and related information, and Andy Altemos, who was instrumental in the shipping regulations analysis. Finally, we thank Ken Heitner and Dana O'Hara of DOE for their leadership and support in directing and sponsoring the EH\&S program and these assessments.

Approved for the

NATIONAL RENEWABLE ENERGY LABORATORY

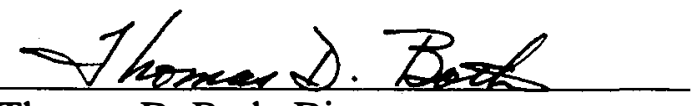

Thomas D. Bath, Director

Analytic Studies Division

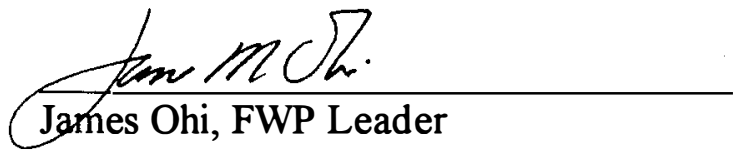




\section{Executive Summary}

An analysis of the environmental, health, and safety (EH\&S) issues for any new technology is an important part of the commercialization of that technology. This is particularly trie of transportation-based technologies, such as advanced batteries for electric vehicles (EVs), because safety is a critical factor for consumer acceptance. Because many EV batteries contain wastes considered hazardous by the Environmental Protection Agency (EPA), it is also important to consider environmental issues associated with battery systems, such as the end-of-life recycling or reclamation of $\mathrm{EV}$ batteries. The purpose of this report is to identify important EH\&S issues for lithium solid polymer electrolyte (SPE) EV batteries and to assess where further analysis of EH\&S issues is needed.

Although lithium batteries that do not have an SPE are also being considered for EV applications, this report focuses only on those lithium battery technologies that utilize the SPE technology. The lithium SPE battery technologies considered in this report may contain metallic lithium or nonmetallic lithium compounds (e.g., lithium intercalated carbons) in the negative electrode.

This EH\&S assessment covers five topics: cell and battery safety, toxicity of lithium SPE battery materials, workplace health and safety issues, recycling and reclamation issues, and SPE battery shipping. In general, the findings of this report are that SPE cells and batteries could be designed so that they present few EH\&S risks.

Lithium SPEs are being investigated, in part, because of the added safety that these systems are anticipated to have compared to lithium batteries without SPEs. Lithium SPE cells have been proposed as the medium to move lithium ions in the battery, thus alleviating some of the problems encountered in liquid electrolyte designs, such as a reaction with the lithium negative electrode, gas venting, and the need for sophisticated seals to contain the liquids.

No information was available on the reactivities of the various nonmetallic lithium SPE electrode materials (or any of the SPE materials). Therefore, it is not known exactly how reactive they would be if the cell were breached or if the electrolyte failed and a cell were short-circuited. However, the rate of propagation of a chemical fire and the rate of penetration of water, air, or both would be slowed by the solid-state nature of the electrode and electrolyte materials.

Because lithium SPE cells are still under development (i.e., no final cell chemistries have been selected for commercialization), specific recommendations for the development of safety mechanisms for cells are difficult. However, the future development of lithium SPE cells should include a detailed evaluation of cell safety. To perform a detailed safety evaluation, safety tests must be conducted. However, because this work is being conducted by industry, none of this information is currently available because of the proprietary nature of the technology development. 
Before commercialization of lithium SPE batteries takes place, safety tests should be conducted and be made available for analysis. These tests should include drop tests, fire tests, abusive overcharging and overdischarging tests (e.g., short-circuit tests), and testing of battery thermal management systems.

There is a potential for human exposure to lithium SPE system materials during use and during the manufacture and recycling of batteries. Because of this, the toxicity and potential carcinogenicity of lithium battery materials were analyzed. In addition, Occupational Safety and Health (OS\&H) standards for the different cell materials are presented. Because of the wide variety of materials being used in the research of lithium SPE cells, hazards of all potential materials are not determined here. However, toxic ity and carcinogenicity issues exist for some potential cell materials, including lithium hexafluoroarsenate, nickel dioxide, vanadium oxides, and titanium dioxide. As new cell chemistries are evaluated for commercialization of lithium SPE batteries, the toxicity of cell materials should be evaluated.

In the recycling and reclamation analysis of lithium SPE batteries, existing facilities that dispose of lithium batteries (non-SPE type) were reviewed. All these facilities use hydrolysis to deactivate the metallic lithium in these batteries. At present, it is not economical for these facilities to recycle the lithium. Because lithium SPE EV batteries will not contain very much, if any, lithium metal (in the range of $5 \mathrm{~kg}$ for a $25-\mathrm{kWh} \mathrm{EV}$ battery), it may not be economical to recycle the lithium from SPE systems. However, the bulk of a lithium SPE EV battery will be composed of metals (e.g., stainless steel) and plastics, and many of these materials may be recycled.

Metallic lithium is very reactive with water and air. However, for many types of lithium SPE batteries (e.g., batteries utilizing negative electrodes with intercalated carbons), no metallic lithium would be used in the cells; instead, lithium in its ionic form would be used. Nonmetallic lithium compounds are less reactive than metallic lithium, but with current information, it could not be determined how much less reactive they are than metallic lithium. The reactivity of nonmetallic lithium compounds affects all the EH\&S issues discussed in this report. For example, it would affect cell safety in the case of a breach of the outer cell can, and it would affect the feasibility of using hydrolysis to deactivate lithium SPE cells. Therefore, tests should be conducted to determine the reactivity of nonmetallic lithium materials, such as lithium SPEs and lithium intercalated carbons.

Because the lithium SPE battery is a developing technology, the exact chemistries and associated constituents are generally proprietary. Nevertheless, it is possible to generally assess the transport requirements applicable to lithium SPE batteries and cells if they are considered to be "articles" transported under the "LITHIUM BATTERY" entry and associated transport provisions in the regulations. As such, any hazardous material other than lithium or a lithium alloy that may be present in the battery or cell need not be specifically taken into account to determine the requirements applicable to the device. 
In addition, the quantity of lithium or lithium alloy present in a battery or cell is a critical factor when considering shipping requirements. It is anticipated that most, if not all, batteries and cells intended to be employed in EV applications will contain quantities of lithium or a lithium alloy exceeding the quantity limitations specified in the domestic and international regulations. Therefore, special written approvals will be necessary from the respective transport regulatory authorities with jurisdiction. 


\section{Table of Contents}

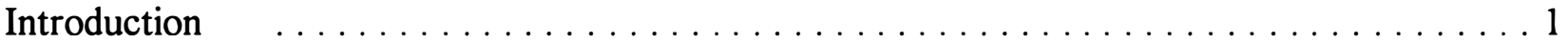

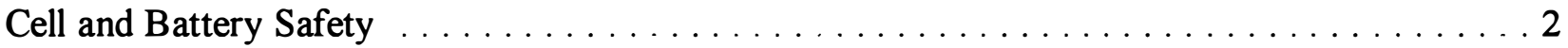

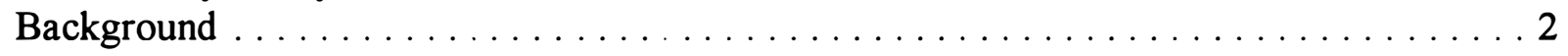

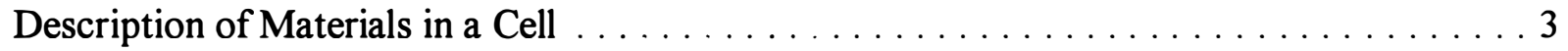

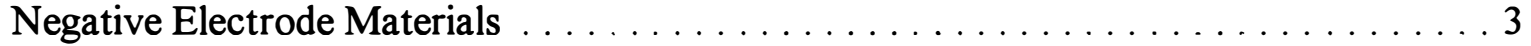

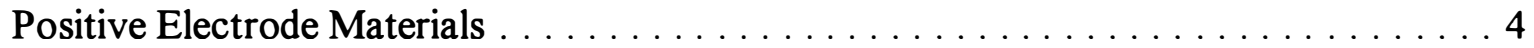

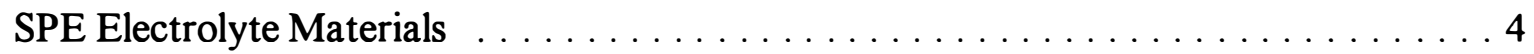

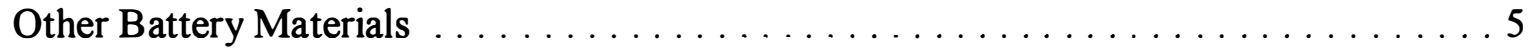

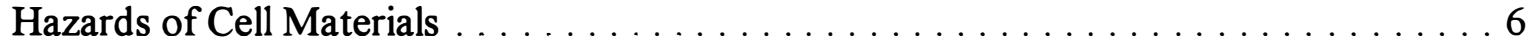

Factors Affecting the Safety of Cells and Batteries $\ldots \ldots \ldots \ldots \ldots \ldots$

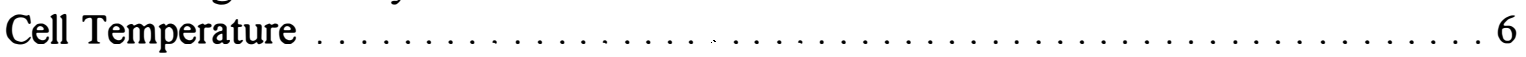

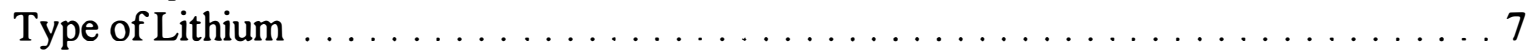

Solid Form of Electrolyte and Electrodes $\ldots \ldots \ldots \ldots \ldots \ldots \ldots \ldots \ldots$

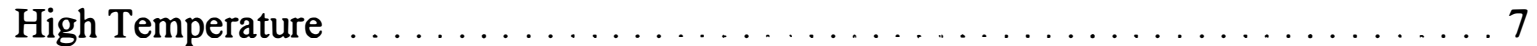

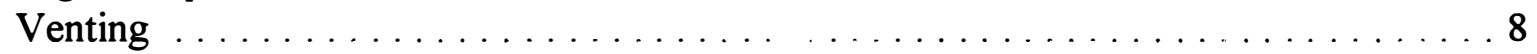

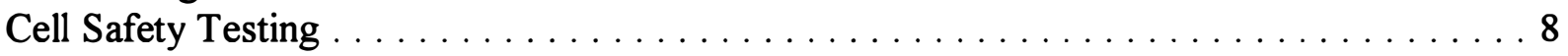

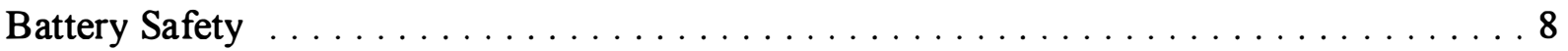

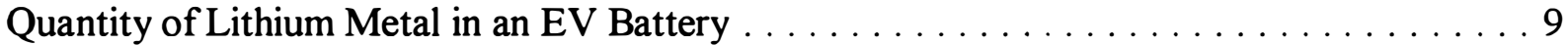

In-Vehicle Safety Aspects of Lithium SPE Batteries $\ldots \ldots \ldots \ldots \ldots \ldots \ldots \ldots$

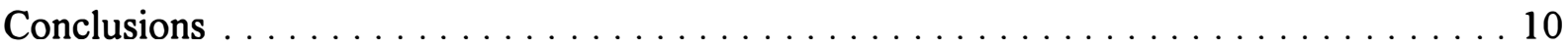

Toxicity of Lithium SPE Battery Materials $\ldots \ldots \ldots \ldots \ldots \ldots \ldots \ldots \ldots \ldots \ldots \ldots \ldots$

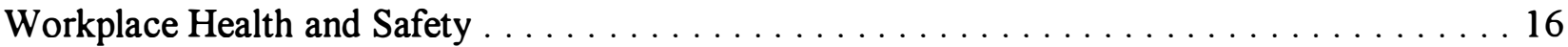

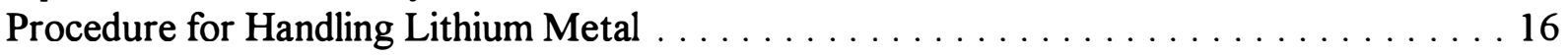

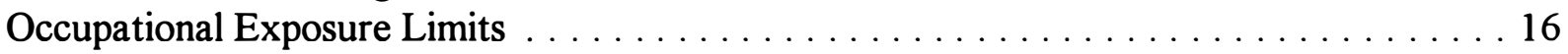

Reclamation and Recycling of Lithium SPE Electric Vehicle Batteries . . . . . . . . . . 19

Background . . . . . . . . . . . . . . . . . . . . . . . . . . 19

Regulations for Determining the Hazardous Classification of Lithium

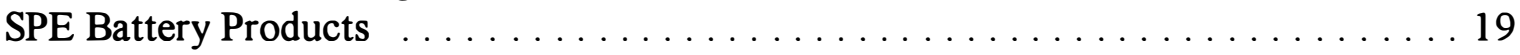

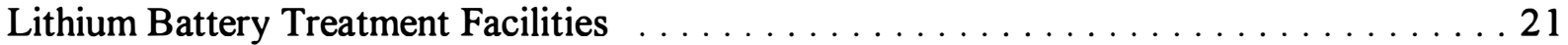

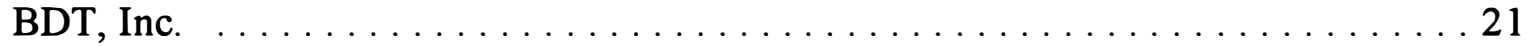

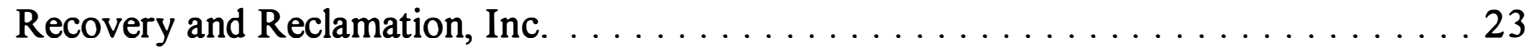

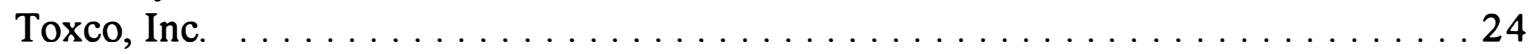

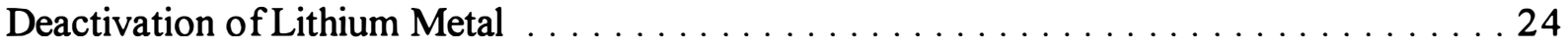

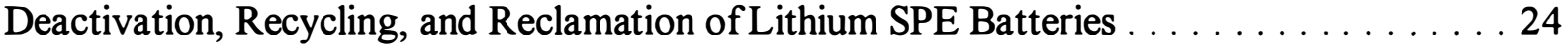

Shipping Requirements for Lithium SPE Batteries $\ldots \ldots \ldots \ldots \ldots \ldots \ldots \ldots \ldots \ldots \ldots$

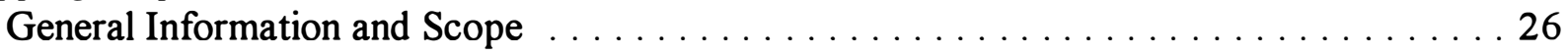

Overview of Transportation Regulations $\ldots \ldots \ldots \ldots \ldots \ldots \ldots \ldots \ldots \ldots \ldots \ldots$

United Nations Recommendations $\ldots \ldots \ldots \ldots \ldots \ldots \ldots \ldots \ldots \ldots \ldots \ldots \ldots \ldots \ldots$

Domestic Transportation Requirements $\ldots \ldots \ldots \ldots \ldots \ldots \ldots \ldots \ldots \ldots \ldots \ldots \ldots \ldots \ldots \ldots$ 
International Sea and Air Transport Requirements $\ldots \ldots \ldots \ldots \ldots \ldots \ldots \ldots \ldots \ldots$

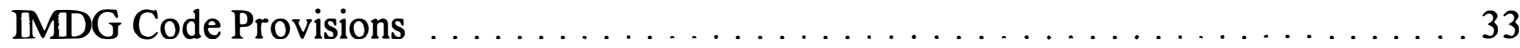

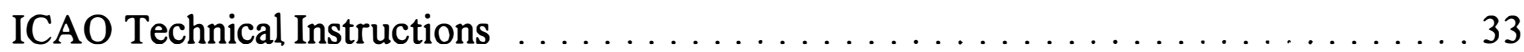

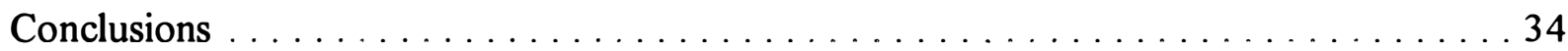

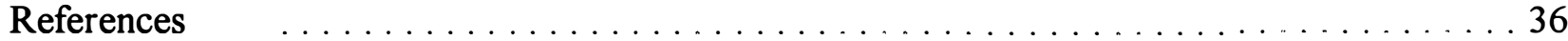

Appendices

A. Toxicity Summaries for Potential Lithium Polymer

Battery Constituents . . . . . . . . . . . . . . . . . . . . . . . . . A-1

B. General Conditions Governing the Classification and Transport of Lithium Batteries Under the United Nations Recommendations . . . . . . . . . . . B-1

C. United Nations Recommendations: Test Methods and

Criteria for Lithium Cells and Batteries

D. General Conditions Governing the Transport of Lithium

Batteries and Cells Under the Department

of Transportation Regulations

D-1 


\section{List of Tables}

Potential Materials Contained in Lithium SPE Batteries $\ldots \ldots \ldots \ldots \ldots \ldots \ldots \ldots$

2 Materials Commonly Used in the Production of Lithium SPE Batteries . . . . . . . . 13

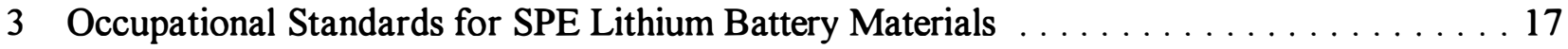

4 EPA Hazardous Waste Limits for Toxic Wastes . . . . . . . . . . . . . . . . . . . . . . . 20

\section{List of Figures}

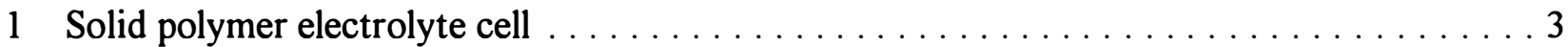

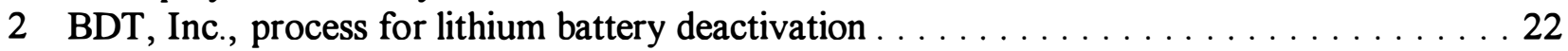

3 Recovery and Reclamation, Inc., process for separating components of lithium batteries 


\section{Introduction}

Lithium solid polymer electrolyte (SPE) batteries are being investigated by researchers worldwide as a possible energy source for future electric vehicles (EVs). One of the main reasons for interest in lithium SPE battery systems is the potential safety features they offer as compared to lithium battery systems using inorganic and organic liquid electrolytes. However, the development of lithium SPE batteries is still in its infancy, and the technology is not envisioned to be ready for commercialization for several years.

Because the research and development (R\&D) of lithium SPE battery technology is of a highly competitive nature, with many companies both in the United States and abroad pursuing R\&D efforts, much of the information concerning specific developments of lithium SPE battery technology is proprietary. This report is based on information available only through the open literature (i.e., information available through library searches). Furthermore, whereas R\&D activities for lithium SPE cells have focused on a number of different chemistries, for both electrodes and electrolytes, this report examines the general environmental, health, and safety (EH\&S) issues common to many lithium SPE chemistries. However, EH\&S issues for specific lithium SPE cell chemistries are discussed when sufficient information exists.

Although lithium batteries that do not have a SPE are also being considered for EV applications, this report focuses only on those lithium battery technologies that utilize the SPE technology. The lithium SPE battery technologies considered in this report may contain metallic lithium or nonmetallic lithium compounds (e.g., lithium intercalated carbons) in the negative electrode.

This report consists of six chapters in addition to this introduction. In "Cell and Battery Safety," a brief overview of lithium SPE cells is given from a safety viewpoint. In addition, safety features are discussed as they relate to types of cell materials, and potential hazards associated with lithium SPE batteries are discussed. The chapter, "Toxicity of Lithium SPE Battery Materials," discusses toxicity issues for a wide variety of lithium SPE battery chemistries. In "Workplace Health and Safety," worker exposure limits for lithium SPE materials are given, and EH\&S issues related to lithium SPE battery manufacturing are examined. The "Reclamation and Recycling of Lithium SPE Electric Vehicle Batteries" chapter provides an overview of existing commercial lithium battery recycling and reclamation processes and discusses the development of cost-effective processes for recycling and reclamation of SPE systems. In "Shipping Requirements for Lithium SPE Batteries," Department of Transportation and international regulations for the shipment of lithium SPE cells and batteries are analyzed. 


\section{Cell and Battery Safety}

In this section, the important issues affecting the safety of lithium SPE cells for EV applications are discussed. Because lithium SPE cells are still in the beginning stages of development, this assessment is very general in nature. Due to the infancy of the technology, lithium SPE batteries have not been built on a commercial scale to date, hence safety aspects of lithium SPE batteries are discussed only in a generic manner. A general description of lithium SPE cells is given prior to the discussion on cell and battery safety.

\section{Background}

The discovery and characterization of ion conducting polymeric membranes has provided for the possibility of developing new types of lithium batteries. Research activities are being conducted all over the world on lithium SPE batteries, but significant advances are required before the technology can be commercialized.

The lithium SPE battery is an all-solid-state system. Although designs vary, the most common form of the lithium SPE cell combines a lithium ionic conducting membrane with two lithium reversible electrodes. A key component in the cell is the polymeric ionic membrane that acts both as an electrolyte and as a separator. The polymer membrane is typically a high molecular weight polymer (e.g., Polyethylene Oxide [PEO]) with a dissolved lithium salt ( $\mathrm{LiX})$. The negative electrode is typically a lithium metal foil or a lithiated intercalated carbon, whereas the positive electrode is based on a reversible intercalation compound blended with the PEO-LiX electrolyte and carbon to form a plastic composite that is backed by a metal foil current collector. A schematic of a generic lithium SPE cell is shown in Figure 1 (Landgrebe 1993).

The chemical reactions for some lithium chemistries are generalized by the following equation (Landgrebe 1993).

$$
\mathrm{C}+\mathrm{Li}_{\mathrm{x}} \mathrm{M}_{\mathrm{y}} \mathrm{N}_{\mathrm{z}}
$$

$(-) \quad(+)$

[fully discharged state]

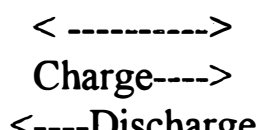

$<----D i s c h a r g e$
$\mathrm{Li}_{\mathrm{x}} \mathrm{C}+\mathrm{M}_{\mathrm{y}} \mathrm{N}_{\mathrm{z}}$

$(-) \quad(+)$

[fully charged state] 


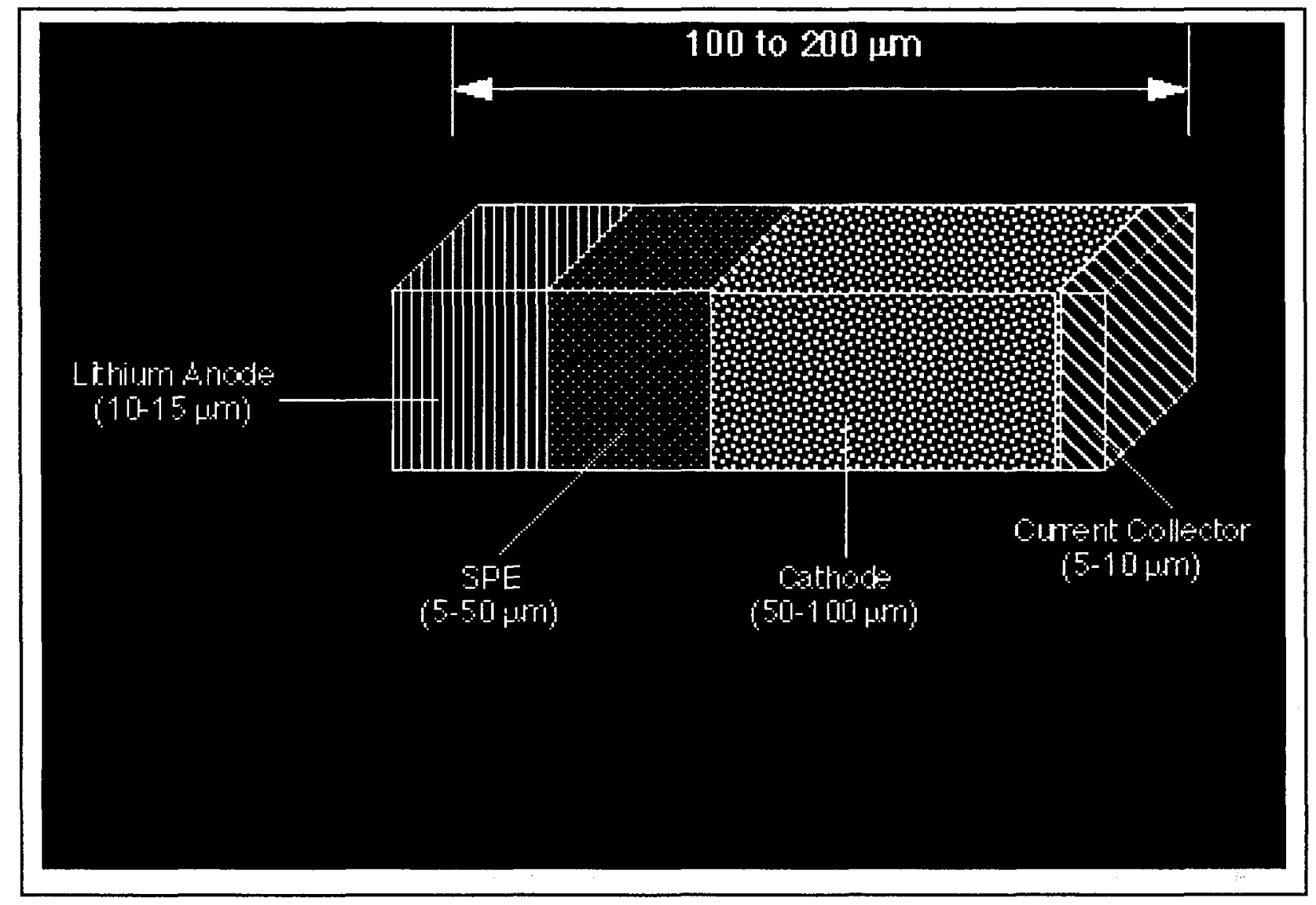

Figure 1. Solid polymer electrolyte cell

As an example, the cell reaction for a lithium manganese dioxide cell, which has received considerable attention from the lithium SPE research community, is shown below.

$$
6 \mathrm{C}+\mathrm{LiMn}_{2} \mathrm{O}_{4} \quad<--------->\quad \mathrm{LiC}_{6}+2 \mathrm{MnO}_{2}
$$

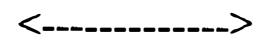

\section{Description of Materials in a Cell}

\section{Negative Electrode Materials}

Lithium, lithium alloys, and lithium intercalated carbons $\left(\mathrm{Li}_{\mathrm{x}} \mathrm{C}\right)$ all can be used as negative electrode materials in a lithium SPE cell. Concerns about the safety of lithium metal, because of its low melting point and high reactivity with most liquid electrolytes, led to the investigation of lithium alloys. However, the use of lithium alloys was shown to result in a decrease in capacity in ambient temperature cells because of poor anode utilization at high current densities (Doddapaneni 1991).

Recently, lithium intercalated graphitic carbons $\left(\mathrm{Li}_{x} \mathrm{C}\right)$ have been evaluated as negative electrodes, 
because they offer chemical stability, improved cycle life, and safety. The carbons have layered graphitic structures where the lithium can be intercalated (Owens and Douglas 1991). One of the advantages of $\mathrm{Li}_{\mathrm{x}} \mathrm{C}$ composite negative electrodes over metallic lithium is that no metallic lithium is generated, thereby enhancing the safety of the cell.

\section{Positive Electrode Materials}

Inorganic insertion/intercalation compounds have been used in lithium SPE cells. Common positive electrode intercalation compounds used by lithium $\mathrm{SPE}$ cells are lithium vanadium oxide $\left(\mathrm{LiV}_{6} \mathrm{O}_{13}\right)$, lithium vanadium bronze $\left(\mathrm{LiV}_{3} \mathrm{O}_{8}\right)$, lithium titanium disulfide $\left(\mathrm{LiTiS}_{2}\right)$, lithium titanium dioxide $\left(\mathrm{LiTiO}_{2}\right)$, and lithium manganese oxides (e.g., $\left.\mathrm{LiMn}_{2} \mathrm{O}_{4}\right)($ Scrosati 1993). In addition, research has been conducted on lithium SPE cells with solid transition metal chalcogenide positive electrodes. One of the characteristics of metal chalcogenide compounds is that they have layered structures, and this property allows reversible lithium intercalation (Doddapaneni 1991). The bonding between the metal chalcogenide and lithium is purely ionic.

\section{SPE Electrolyte Materials}

The polymer membrane, which acts as both a lithium ion conductor and a separator for the two electrodes, is typically composed of a high molecular weight polymer with a dissolved lithium salt $\mathrm{LiX}$. The most common polymer electrolyte is polyethyleneoxide (PEO) complexed with an appropriate electrolyte salt, e.g., $\mathrm{LiClO}_{4}, \mathrm{LiAsF}_{6}, \mathrm{LiBF}_{4}$, or $\mathrm{LiN}\left(\mathrm{CF}_{3} \mathrm{SO}_{2}\right)_{2}(\mathrm{Scrosati}$ 1993); however, there are many other polymeric chemistries for which research is being conducted.

As an alternative to polymer modification, plasticizers have been added to polymers to reduce crystallinity, resulting in an increase in ionic conductivity (Fateaux et al. 1993). However, the presence of a large quantity of liquid plasticizer changes the polymer to a semi-solid status (i.e., a gelled polymer). According to Fateaux et al., this reduces the following benefits associated with the use of SPEs:

- control of ionic mobilities

- low interfacial impedance

- cell design flexibility.

More research is needed on plasticizers; therefore, the rest of this report emphasizes the EH\&S issues for lithium SPE systems without plasticizers; gelled polymer cells are only briefly discussed. 


\section{Other Battery Materials}

A current collector, most likely made of copper or aluminum, is included in the cell design. Individual cells will be connected together to form a battery, which will be surrounded by thermal insulation, probably a low thernal conductivity material such as polyurethane. The battery case could be polypropylene, reinforced polypropylene, or polystyrene. A listing of some potential materials used in lithium SPE batteries is shown in Table 1.

Table 1. Potential Materials Contained in Lithium SPE Batteries

\begin{tabular}{|c|c|}
\hline Material & Function \\
\hline Aluminum & Current collector \\
\hline Carbon & Anode and addition to cathode \\
\hline Copper & Current collector \\
\hline Dimethyl carbonate & Plasticizer \\
\hline Dimethyl ether & Plasticizer \\
\hline Ethylene carbonate & Plasticizer \\
\hline Graphite & Anode and addition to cathode \\
\hline $\begin{array}{l}\text { Lithium and lithium } \\
\text { compounds }\end{array}$ & $\begin{array}{c}\text { May include } \mathrm{LiPF}_{6}, \mathrm{LiBF}_{4}, \mathrm{LiCF}_{3} \mathrm{SO}_{3}, \\
\left.\mathrm{LiClO}_{4}, \mathrm{LiAsF}_{6}, \mathrm{LiNCF}_{3} \mathrm{SO}_{2}\right]_{2}, \mathrm{Li}_{x} \mathrm{CoO}_{2}, \mathrm{Li}_{x} \mathrm{NiO}_{2} \mathrm{Li}_{x} \mathrm{Mn}_{2} \mathrm{O}_{4}, \mathrm{LiV}_{6} \mathrm{O}_{13}, \\
\mathrm{LiV}_{3} \mathrm{O}_{8}, \mathrm{LiTiS}_{2}, \mathrm{LiTiO}_{2}\end{array}$ \\
\hline Manganese dioxide $\left(\mathrm{MnO}_{2}\right)$ & Cathode \\
\hline Methyl formate & Plasticizer \\
\hline Polyacrylonitrile & Polymer \\
\hline Polyethylene glycol acrylate & Polymer precursor \\
\hline $\begin{array}{l}\text { Polyethylene glycol } \\
\text { methacrylate }\end{array}$ & Polymer precursor \\
\hline Polyethylene oxide & Polymer \\
\hline Polyphosphazene & Polymer \\
\hline Polypropylene oxide & Polymer \\
\hline Polysiloxane & Polymer \\
\hline Polyvinylidene fluoride & Binder \\
\hline Propylene carbonate & Plasticizer \\
\hline Teflon ${ }^{T M}$ & Binder \\
\hline Tetrahydrofuran & Plasticizer \\
\hline
\end{tabular}




\section{Hazards of Cell Materials}

The toxicity and hazardous properties of the materials listed in Table 1 affect the overall safety of a lithium SPE battery in the case of exposure to these materials during an accident or malfunction of a battery. Due to the uncertainty about which constituents will ultimately be used in batteries, this discussion will focus on the material hazard associated with lithium itself. Because the toxicity of the materials listed in Table 1 is a complex issue, and in many cases is not well understood, it is discussed separately in the next section. For the purposes of the safety discussion in this chapter, lithium is considered the primary hazardous cell constituent.

According to the Emergency Response Handbook (DOT 1990), lithium metal and lithium compounds have the following characteristics:

- $\quad$ may ignite spontaneously if exposed to air

- $\quad$ may re-ignite after fire is extinguished

- may ignite in the presence of moisture

- may have violent reactions with water that produce flammable gas

- may create fire or explosive hazard in sewer runoff.

Lithium is a dangerous fire hazard when exposed to heat or flame. In addition, lithium powder may ignite spontaneously in air. The solid metal ignites above $180^{\circ} \mathrm{C}$ (Sax and Lewis 1989). Explosive or violent reactions may occur between lithium and a wide variety of compounds at various elevated temperatures (e.g., violent reactions with sulfur, metal oxides, titanium trioxide, vanadium pentoxide above about $185^{\circ} \mathrm{C}$-the exact temperature varies depending on the material) (Sax and Lewis 1989).

The above hazards data for lithium are for metallic lithium. No hazards data were available in the literature on intercalated lithium compounds, such as the negative electrode $\mathrm{Li}_{\mathrm{x}} \mathrm{C}$ intercalated materials being evaluated for some lithium SPE batteries. The reactivities of lithium intercalated carbons used for negative electrodes would be lower than the pure metallic lithium foils because there would be less lithium available and it would be in the ionic form. Empirical information on the reactivity differences between metallic lithium and ionic lithium (as found in the various compounds being considered for lithium SPE cells) was not available. Therefore, the reactivity levels of the various nonmetallic lithium compounds being used in the development of lithium SPE batteries needs to be estimated so that the safety of the lithium SPE technology can be evaluated further.

\section{Factors Affecting the Safety of Cells and Batteries}

\section{Cell Temperature}

The operating temperatures of different lithium SPE cells vary; some may operate around $60^{\circ} \mathrm{C}$, whereas others operate at temperatures of about $100^{\circ} \mathrm{C}$ in order to provide acceptable levels of ohmic polarization (Owens and Douglas 1991). Some research has been directed toward finding 
new polymer electrolytes with adequate conductivities at ambient temperature. Because most cells operate at slightly elevated temperatures, thermal management systems will likely be included in the design of cells and batteries (this is discussed further in the section on battery safety). For some cell chemistries, there is a potential for harmful gases to be released from a cell in the case of severe overheating (e.g., this could occur when the melting point of lithium is reached in a cell with a lithium metal negative electrode, and the cell ruptures or leaks); therefore, the thermal management system must be designed to prevent severe overheating of cells.

\section{Type of Lithium}

Two types of lithium negative electrode materials are considered in this evaluation: (1) negative electrode material fabricated from metallic lithium foil; and (2) negative electrode material made of carbon-based intercalated compounds of lithium.

In the second type of negative electrode, no free metallic lithium is available, which reduces the reactivity of the lithium in the cell and contributes to overall cell safety. In the first type, the exposure of metallic lithium to ambient air (in the case of cell rupture) is a hazard because of the extreme reactivity of metallic lithium.

\section{Solid Form of Electrolyte and Electrodes}

Because the electrodes are solids (thin films), a breach in the cell protective barrier (i.e., outer can) would result in the exposure of only a limited amount of reactive materials as compared to liquid electrodes. In addition, material would not flow out of the cell can because it is solid. Furthermore, with the nonmetallic lithium electrodes, the lithium would be in the ionic form and would be less reactive than pure metallic lithium. In the case of a breach in the SPE, the electrodes would not flow together because they are both solid.

No information is available in the literature on the reactivities of the various lithium intercalated electrode materials; therefore, it is not known exactly how reactive they would be if the outer cell can were breached or if the electrolyte were cracked and a cell short-circuited. However, the rate of propagation of chemical fire and the rate of penetration of water and/or air will be slowed by the solid-state nature of the electrode and electrolyte materials (A.D. Little 1994).

\section{High Temperature}

Lithium SPE systems have shown good thermal stability up to the lithium melting temperature. However, in cells with metallic negative electrodes, when this temperature is reached, the molten lithium metal may exude from the cell edges, posing a hazard upon exposure to air or water (A.D. Little 1994). Although this report focuses on lithium SPE systems, it is noted that gelled-polymer electrolytes can be expected to have much lower thermal stability properties. The liquid plasticizer is likely to vaporize, generating internal pressure buildup. If lithium is melted in the presence of liquid plasticizer, rapid decomposition of the electrolyte can occur (A.D. Little 1994). The potential for cell rupture due to plasticizer and electrolyte reactions was not evaluated. 


\section{Venting}

Lithium SPE systems should not require venting mechanisms because there are no volatile compounds emitted during charging and discharging (A.D. Little 1994). Because the cell materials in lithium SPE systems are solids, cells would not be subject to venting caused by the volatility of cell materials unless the solid materials underwent a phase change from solid to gas. However, this would not occur under normal operating temperatures (i.e., in the $50^{\circ}$ to $100^{\circ} \mathrm{C}$ range, depending on the specific chemistry). In extreme cases, a fire could result in a change of state that would induce venting because a lithium metal electrode could melt; however, in this case, combustion of the polymer itself would also be a hazard. Gelled-polymer systems would probably require vents because of the volatile organic compounds emitted from the electrolyte.

\section{Cell Safety Testing}

Although there have been detailed cell safety tests reported in the literature for nonrechargeable lithium battery types, there were no detailed cell safety tests published for lithium SPE cells. The only tests that were cited in the literature for lithium SPE systems were performed by Harwell in England (Hooper 1989).

Cell safety tests conducted by Harwell reported that mixtures of lithium SPE cell components did not show explosive tendencies, even when heated to temperatures exceeding the melting point of lithium (Hooper 1989). It was also reported that lithium SPE cells were very resistant to electrical abuse, including short-circuit, because of transport limitations within the polymer electrolyte associated with anionic transport (Hooper 1989). At Harwell, a 1 Ah cell operating at $120^{\circ} \mathrm{C}$ showed a temperature excursion of only $1^{\circ}$ to $2^{\circ} \mathrm{C}$ when subjected to an external short-circuit (Hooper 1989). However, no other information was available on the specific methods of the testing, or on the specific SPE cell chemistries for which the tests were conducted. Furthermore, it could not be determined whether the cells that Harwell tested were uncycled or cycled cells, and this could affect reactivity. (It was reported that uncycled cells with liquid electrolytes and metallic lithium electrodes exhibit better safety behavior than cycled cells, because replated lithium has a different morphology, making it more reactive [Abraham 1994].)

\section{Battery Safety}

Although the safe use of lithium SPE batteries for vehicular propulsion begins with cell safety, an electric vehicle battery will consist of many hundreds of mechanically and electrically interconnected cells in an enclosure. This situation introduces additional safety concerns not necessarily considered on the cell level. Because there are no existing lithium SPE EV batteries, no information is available on battery designs. Nevertheless, general considerations for lithium SPE EV batteries are briefly discussed.

Important components of battery design include the following: electrical networking; electrical insulation; battery enclosure, including any thermal management requirements; and electrical and mechanical interfaces with battery controllers and chargers. 
A good electrical network design will accommodate cell failure with minimal effect on battery performance. Some EV battery designs for other advanced battery technologies (e.g., sodium-sulfur) allow for cell failures to be isolated within cell modules, resulting in the loss of a minimal number of cells under such circumstances. For some EV batteries, cell modules may be individually monitored electrically to detect charge imbalances caused by cell failure or cell aging.

During short circuit conditions, the behavior of lithium SPE batteries would be affected by the battery system design, including any electronics designed to limit battery damage that could occur. During a short-circuit within the battery, the battery resistance would significantly decrease, with the battery approaching the behavior of a current-carrying wire. However, a potential design approach to limit damage during a short circuit of an SPE system could include the use of electronics, with each individual cell (or group of small cells) fused so that when current draw is excessive, the fuse would trip and the cell or group of cells would be separated from the main circuit. Damage from a short-circuit would be limited to individual cells or small groups of cells, and the battery itself would be protected.

Other important aspects of battery design include electrical insulation, battery enclosure, and electrical and mechanical interfaces with battery controllers. Electrical insulation, although generally considered a standard precaution in any type of storage battery, would be extremely important for high-energy lithium polymer EV batteries because of the high current levels generated by the battery pack. Although safety standards exist for the electrical insulation of lead-acid storage batteries (SAE 1986), no such standards currently exist for EV batteries.

Battery enclosures would also be an important part of overall safety for a lithium SPE EV battery. Although lithium SPE systems are not considered to be high temperature batteries, they do generate heat; therefore, thermal design parameters should be incorporated into the battery enclosures. In addition to providing for thermal management, battery enclosures should be designed to meet existing safety guidelines and practices (e.g., batteries should be properly secured). Electrical and mechanical interfaces with battery chargers and controllers should be designed to meet all appropriate standards and guidelines, including all electrical safety practices and good engineering design criteria.

\section{Quantity of Lithium Metal in an EV Battery}

As mentioned previously, two types of lithium negative electrode materials were considered in this evaluation: (1) negative electrode material fabricated from metallic lithium foil and (2) negative electrode material made of carbon-based intercalated compounds of lithium. In the second type of negative electrode, no free metallic lithium is available. In the first type, metallic lithium is used, to which the following discussion applies.

If a lithium SPE EV cell has a cell voltage of $4 \mathrm{~V}$, and is designed to have three times the stoichiometric lithium needed for full cell discharge, then approximately $0.2 \mathrm{~kg}$ of lithium metal are available per kilowatt-hour (kWh) of battery. A typical EV may have $25 \mathrm{kWh}$ of energy and, therefore, approximately $5 \mathrm{~kg}$ of lithium metal. 
If accidental battery damage caused exposure of the lithium metal to water, then the following reaction would occur:

$$
2 \mathrm{Li}+2 \mathrm{H}_{2} \mathrm{O}----->2 \mathrm{LiOH}+\mathrm{H}_{2}
$$

generating 1 mole of hydrogen gas per 2 moles of lithium metal.

The potential energy content of that hydrogen would be:

$$
\begin{gathered}
\frac{1 \mathrm{~mol} \mathrm{H}_{2}}{2 \mathrm{~mol} \mathrm{Li}} \times \frac{2.02 \mathrm{~g} \mathrm{H}_{2}}{1 \mathrm{~mol} \mathrm{H}_{2}} \times \frac{1 \mathrm{~mol} \mathrm{Li}}{6.94 \mathrm{~g} \mathrm{Li}} \times 5000 \mathrm{~g} \mathrm{Li}=726 \mathrm{~g} \mathrm{H}_{2} \text { per EV } \\
726 \mathrm{~g} \mathrm{H}_{2} \times \frac{1 \mathrm{~kg}}{1000 \mathrm{~g}} \times \frac{120 \mathrm{MJ}}{1 \mathrm{~kg}}=87 \mathrm{MJ}
\end{gathered}
$$

The total theoretical energy release for the hydrogen would then be approximately $87 \mathrm{MJ}$ (North American 1978). However, this is a theoretical energy release and only serves as an upper bound estimate. The actual oxidation would require some time, and side reactions would reduce the hydrogen generation rate. In addition, because lithium SPE batteries would be made of many stacked cells, it is extremely unlikely that all of the lithium would be reacted at one time during an accident. Therefore, the energy release would be much less.

\section{In-Vehicle Safety Aspects of Lithium SPE Batteries}

The only in-vehicle hazards identified as specific to lithium SPE batteries are those associated with the reactivity of lithium. These were discussed previously. Other in-vehicle safety issues are EV generic, and are not covered because they do not specifically apply to lithium SPE EV batteries. Previous analyses have discussed nonbattery-specific in-vehicle safety issues (Mark 1992).

\section{Conclusions}

Lithium SPEs are being investigated, in part, because of the added safety of these systems compared to lithium batteries with non-SPEs. Lithium SPE cells have been proposed as the medium to move lithium ions in the battery to alleviate some of the problems encountered in liquid electrolyte designs. Such problems include reaction with the lithium negative electrode, gas venting, and the need for sophisticated seals to contain the liquids.

Because the R\&D of lithium SPE cells is still in the beginning stages (i.e., no final cell chemistries have been selected for commercialization), it is difficult to make specific recommendations for the development of safety mechanisms for cells. However, the future development of lithium SPE cells should include a detailed evaluation of cell safety. In order to perform a detailed safety evaluation, safety tests must be conducted. Because this work is currently being conducted by industry, none of this information is currently available because of the proprietary nature of the technology development. Before commercialization of lithium SPE batteries takes place, safety tests should be 
conducted and made available for analysis. These tests should include, as a minimum, drop tests, fire tests, abusive overcharging and overdischarging tests, and testing of battery thermal management systems. 


\section{Toxicity of Lithium SPE Battery Materials}

There is a potential for human exposure to SPE battery materials during use, as well as during the manufacturing and recycling processes. The toxicity and carcinogenicity of lithium battery materials are described in this section. The major constituents found in many of the lithium SPE chemistries under laboratory development (as discussed in the previous section) are evaluated. A detailed discussion of toxicity and carcinogenicity of potential battery materials is presented in Appendix A. Archuleta of Sandia National Laboratory has provided a review of lithium battery materials toxicity (1994).

Potential carcinogenic substances contained in lithium SPE cells and batteries being developed for EVs were evaluated according to guidelines developed by the International Agency for Research on Cancer (IARC) and the National Toxicology Program (NTP). The toxicity of common materials used in the production of lithium SPE batteries was reviewed using secondary sources, including on-line toxicology data bases and industrial hygiene and industrial toxicology texts.

This section summarizes of the toxicity of organic compounds or metals associated with the production of lithium SPE batteries. Table 2 contains an alphabetical list of the cell materials considered. Standard industrial hygiene and toxicology texts were considered in the collection of toxicity information, and a limited on-line literature search was conducted specifically for publications on the toxicity of lithium SPE batteries (Dialog Information Services 1994). The Hazardous Substances Data Bank (HSDB 1994) was searched for the individual chemicals listed.

It should be noted that a comprehensive literature search was not conducted for each of the listed materials, and that additional toxicity information may be available in the medical literature. However, because the industrial hygiene and toxicology texts and data bases reviewed for this report included references to any industrial materials that are known carcinogens, it is unlikely we have excluded discussion of any potential carcinogens.

The Chemical Abstracts Service (CAS) of the American Chemical Society assigns individual identification numbers to unique chemical compositions, to aid in the identification of literature references to a specific material. This comprehensive, numeric system of registry has been widely adopted by commercial and government agencies as a convenient and reliable way of specifying individual chemical entities.

CAS numbers were researched in The Merck Index (1989), in the Hazardous Substances Data Bank (1994), and in the STN International on-line CAS Registry file (STN 1994). The Registry file is a chemical structure and dictionary data base of the unique substance records identified by CAS. Records contain CAS Registry Numbers, commonly used synonyms, polymer class terms, structure diagrams, and molecular formulas, all of which may be searched. However, CAS numbers could not be located for several compounds listed, and toxicity data were not located under the listed name. For some chemicals, no toxicity data were found in either the texts or in the on-line data bases. 
A listing of common materials used in the production of SPE batteries is shown in Table 2 .

Table 2. Materials Commonly Used in the Production of Lithium SPE Batteries

\begin{tabular}{|l|}
\hline Aluminum \\
Carbon \\
Copper \\
Dimethyl carbonate \\
Dimethyl ether \\
Ethylene carbonate \\
Graphite \\
Lithium and lithium compounds (may include $\mathrm{LiPF}_{6}, \mathrm{LiBF}_{4}, \mathrm{LiCF}_{3} \mathrm{SO}_{3}$, \\
$\quad$ LiN[CF $\left.\mathrm{SO}_{2}\right]_{2}, \mathrm{LiClO}_{4}, \mathrm{LiAsF}_{6}, \mathrm{Li}_{x} \mathrm{CoO}_{2}, \mathrm{Li}_{x} \mathrm{NiO}_{2} \mathrm{Li}_{x} \mathrm{Mn}_{2} \mathrm{O}_{4}, \mathrm{LiV}_{6} \mathrm{O}_{43}$, \\
$\quad$ LiV \\
$\left.\mathrm{O}_{8}, \mathrm{LiTiS}_{2}, \mathrm{LiTiO}_{2}\right)$ \\
Manganese dioxide $\left(\mathrm{MnO}_{2}\right)$ \\
Methyl formate \\
Polyacrylonitrile \\
Polyethylene glycol acrylate \\
Polyethylene glycol methacrylate \\
Polyethylene oxide \\
Polyphosphazene \\
Polypropylene oxide \\
Polysiloxane \\
Polyvinylidene fluoride \\
Propylene carbonate \\
Teflon® \\
Tetrahydrofuran \\
\hline
\end{tabular}

Information was gathered regarding the potential carcinogenicity of components of lithium SPE systems, according to the guidelines developed by IARC and NTP. Lists of chemicals addressed in IARC monographs or by NTP were reviewed to determine whether the chemicals listed in Table 2 were studied by either group (IARC 1992; NTP 1993).

IARC monographs are reports from expert panels that have examined all available scientific and medical evidence relevant to specific chemicals. Based on the strength of this evidence, the reports present an assessment of whether, under certain conditions of exposure, an agent could alter the incidence of cancer in humans (IARC 1992). The monographs neither quantitatively estimate risk nor extrapolate from experimental data to humans. Chemicals are selected for IARC review when there is evidence of human exposure, and when there is some evidence or suspicion of carcinogenicity. 
Criteria to evaluate carcinogenic risk to humans include whether there is epidemiological evidence of carcinogenicity in humans. Evidence relevant to human carcinogenicity also may be provided by experimental studies of carcinogenicity in animals and by other biological data, particularly those relating to humans. Relevant data on metabolism and other mechanistic considerations also are considered. The final evaluation by the IARC panel takes into account the total body of evidence and groups the following chemicals according to the strength of the available evidence:

Group 1 The agent is carcinogenic to humans (sufficient evidence of carcinogenicity in humans).

Group 2A The agent is probably carcinogenic to humans (limited evidence of carcinogenicity in humans and sufficient evidence of carcinogenicity in experimental animals).

Group 2B The agent is possibly carcinogenic to humans (limited evidence in humans in the absence of sufficient evidence in experimental animals, or when there is inadequate evidence in humans and there is sufficient evidence in experimental animals).

Group 3 The agent is not classifiable as to its carcinogenicity to humans.

Group 4 The agent is probably not carcinogenic to humans (there is evidence suggesting lack of carcinogenicity in humans together with evidence suggesting lack of carcinogenicity in experimental animals).

Chemicals studied by the NTP are selected on the basis of human exposure, production levels, chemical structure, and available toxicologic data (NTP 1993). NTP uses animal studies as a basis for its conclusions on carcinogenicity. In this type of study, positive results demonstrate that a chemical is carcinogenic for laboratory animals under the conditions of the study and indicate that exposure to the chemical is a potential hazard to humans. Because the experiments are conducted under a limited set of conditions, negative results, in which the study animals do not have a greater incidence of neoplasia than the control animals, do not necessarily mean that a chemical is not a carcinogen.

The following categories of evidence of carcinogenic activity summarize the strength of the experimental evidence, and do not refer to potency:

- CE Clear evidence

- SE Some evidence

- EE Equivocal evidence

- NE No evidence

- IS Inadequate study. 
Appendix A contains the toxicity summaries for the various materials. As new cell chemistries are evaluated for lithium SPE batteries, the toxicity of cell materials should continue to be evaluated. 


\section{Workplace Health and Safety}

This section includes a review of the current procedures for the safe handling and storage of lithium metal and applicable lithium compounds. Occupational, Safety, and Health Administration (OSHA) exposure regulations are also reviewed

\section{Procedure for Handling Lithium Metal}

The U.S. Department of Transportation (DOT) requires a flammable-solid-and-dangerous-whenwet label for lithium metal. The reaction of lithium metal with water generates flammable hydrogen gas. To handle lithium safely, it should be kept in an air-free atmosphere, such as argon, helium, or carbon dioxide, at temperatures below $225^{\circ} \mathrm{C}$. For long term storage, lithium is placed in air tight containers in mineral oil (Kirk-Othmer 1978).

According to the Emergency Response Handbook (DOT 1990), lithium batteries, lithium metal, and lithium compounds have the following characteristics:

- may ignite spontaneously if exposed to air

- may re-ignite after fire is extinguished

- may ignite in the presence of moisture

- may have violent reactions with water that produce flammable gas

- may create a fire or explosive hazard in sewer runoff.

Lithium fires should be extinguished with dry sand, Lith-X® powder, or G-1 graphite powder. The UN number for lithium metal is 1415 (DOT 1990).

\section{Occupational Exposure Limits}

The occupational exposure limits of certain battery materials are summarized in Table 3. OSHA promulgates these standards, which are in the form of time-weighted average (TWA) permissible exposure limits (PELs). A TWA PEL is an employee's average airborne exposure in any 8-hour work shift of a 40 -hour week.

Table 3 excludes battery materials that have no occupational exposure limit at this time.

Safety issues during the manufacture of lithium SPE batteries impact handling of battery materials, cell assembly, and cell packaging. Lithium-ion-based $\left(\mathrm{Li}_{\mathrm{x}} \mathrm{C}\right)$ negative electrodes usually are prepared as carbon powder from the pyrolitic decomposition of polymeric materials. The carbon powders are obtained by conventional grinding processes. The lithium intercalated transition metal oxide powders (e.g., $\mathrm{LiMn}_{2} \mathrm{O}_{4}$, and $\mathrm{LiNiO}_{2}$ ) are obtained by the thermal decomposition of precursor mixtures such as lithium nitrate/carbonate and manganese oxide. The metal oxide powders are reduced to powder using conventional grinding techniques. Care should be taken when handling these materials. 
Table 3. Occupational Standards for Lithium SPE Battery Materials

\begin{tabular}{|c|c|}
\hline Species & Standard \\
\hline Aluminum (alkyls) & $2 \mathrm{mg} / \mathrm{m}^{3}$ \\
\hline Aluminum (metal dust) & $10 \mathrm{mg} / \mathrm{m}^{3}$ \\
\hline Aluminum (pyro powders) & $5 \mathrm{mg} / \mathrm{m}^{3}$ \\
\hline Aluminum (soluble salts) & $2 \mathrm{mg} / \mathrm{m}^{3}$ \\
\hline Aluminum (welding fumes) & $5 \mathrm{mg} / \mathrm{m}^{3}$ \\
\hline Copper (dusts and mists) & $1 \mathrm{mg} / \mathrm{m}^{3}$ \\
\hline Copper (fume) & $0.2 \mathrm{mg} / \mathrm{m}^{3}$ \\
\hline Copper (fume) & $0.1 \mathrm{mg} / \mathrm{m}^{3}$ \\
\hline Graphite (all forms except fibers) & $2 \mathrm{mg} / \mathrm{m}^{3}$ \\
\hline $\begin{array}{l}\text { Graphite, synthetic (respirable } \\
\text { fraction) }\end{array}$ & $5 \mathrm{mg} / \mathrm{m}^{3}$ \\
\hline Graphite, synthetic (total dust) & $15 \mathrm{mg} / \mathrm{m}^{3}$ \\
\hline Lithium hydride & $0.025 \mathrm{mg} / \mathrm{m}^{3}$ \\
\hline Lithium hexafluoroarsenate (as As) & $0.01 \mathrm{mg} / \mathrm{m}^{3}$ \\
\hline Manganese dust \& compounds & $5 \mathrm{mg} / \mathrm{m}^{3^{*}}$ \\
\hline Manganese fume & $1 \mathrm{mg} / \mathrm{m}^{3^{\circ}}$ \\
\hline Methyl formate & $250 \mathrm{mg} / \mathrm{m}^{3}(100 \mathrm{ppm})$ \\
\hline Nickel dioxide & $1 \mathrm{mg} / \mathrm{m}^{3^{* *}}$ \\
\hline Titanium dioxide (total dust) & $10 \mathrm{mg} / \mathrm{m}^{3}$ \\
\hline Tetrahydrofuran & $590 \mathrm{mg} / \mathrm{m}^{3}(200 \mathrm{ppm})$ \\
\hline $\begin{array}{l}\text { Vanadium pentoxide (respirable dust } \\
\text { \& fume) }\end{array}$ & $0.05 \mathrm{mg} / \mathrm{m}^{3}$ \\
\hline \multicolumn{2}{|c|}{ 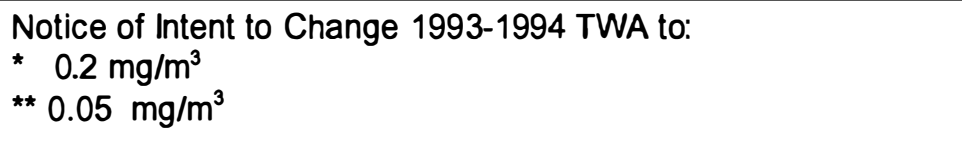 } \\
\hline Source: ACGIH 1993-1994 and OSH & \\
\hline
\end{tabular}

Lithium salts tend to be hygroscopic and, as described in an earlier section, in some cases, toxic. Salts should be handled in low humidity environments to avoid reactions. Toxic salts should be handled with care to avoid respirable or ingestive contamination.

Polymer precursors such as acrylates, methacrylates, and epoxies may be skin irritants, and direct skin contact should be avoided. Additionally, many of these materials may be combustible and should be handled away from ignition sources.

Some of the solvents, especially in the high molecular weight polymer coating processes and in the preparation of gelled-polymer electrolyte systems, can have low boiling points, and therefore, 
present several safety issues: (1) combustible, (2) explosive hazard, (3) easily respirable, and (4) eye and skin irritant. The solvents can be low molecular weight hydrocarbons, ethers, and carbonates.

Unlike the liquid-based lithium battery system, the SPE system includes the electrolyte component during cell assembly (in liquid systems the electrolyte is generally added after the cell is assembled). Consequently, it is conceivable that in some circumstances the cell/battery could be short-circuited during manufacturing. 


\section{Reclamation and Recycling of Lithium SPE Electric Vehicle Batteries}

\section{Background}

Reclamation and recycling of spent lithium SPE batteries are important issues that must be addressed as part of the commercialization process. The use of lithium SPE batteries in EVs will result in significant environmental benefits, and the disposal of spent batteries should not detract from those benefits. Because lithium SPE systems contain lithium, which is considered a hazardous waste by the EPA, the end-of-life disposal of lithium SPE batteries may be regulated by EPA hazardous waste disposal rules.

This section discusses EPA regulations for the disposal, recycling, or reclamation of lithium SPE system constituents. Various constituents of a spent lithium SPE battery could be handled differently. Some components of a battery may be recycled. Some may be reused and made into a marketable product (this is classified as reclamation by the EPA). Other materials of a spent battery may have to be discarded. In addition to discussing EPA regulations, this section also examines operating battery recycling processes for existing types of lithium batteries (non-SPE types).

\section{Regulations for Determining the Hazardous Classification of Lithium SPE Battery Products}

A heightened awareness of environmental concerns has resulted in an increased interest in waste disposal methods. Under existing EPA regulations, hazardous wastes cannot be disposed of in landfills. Recycling or reclamation of wastes, as opposed to disposal, is a primary objective of the EPA; therefore, the recyclability of new products is always an important consideration.

Solid waste disposal in the United States is regulated under the Resource Conservation and Recovery Act (RCRA), and it is the responsibility of the EPA to develop regulations to carry out and enforce RCRA. The primary objectives of RCRA are to protect human health and the environment and to conserve valuable material and resources (Haney and Casler 1990). Previous analyses have examined the impact of RCRA on EV battery recycling (Corbus 1992, 1992a).

A waste is defined as hazardous by the EPA if it exhibits any of the following characteristics: ignitability, reactivity, corrosivity, and toxicity. Toxicity is a particularly important hazardous waste characteristic because, unlike the other three that often are treatable through specific processes (e.g., neutralizing corrosive wastes), toxic materials are always considered hazardous if their concentrations are above certain EPA standards. Toxic materials can be removed from waste, rendering the remaining waste as nonhazardous, but the toxic materials themselves are still considered hazardous. These toxic materials can be recycled, as is done with lead-acid batteries.

The disposal of batteries that contain hazardous wastes is difficult because of EPA regulations that ban hazardous waste land disposal (EPA 1990). These regulations require that all hazardous wastes 
containing toxic metals be treated to be non leachable before disposal. Table 4 lists the main contaminants regulated for toxicity by the EPA that may be found in different types of batteries. The concentrations listed are the maximum concentrations allowable in a waste before it is considered hazardous by the EPA.

Table 4. EPA Hazardous Waste Limits for Toxic Wastes *

\begin{tabular}{||l|c||}
\hline Concentration & $\begin{array}{c}\text { Contaminant Maximum } \\
\text { (mg/L) }\end{array}$ \\
\hline Arsenic & 5.0 \\
\hline Cadmium & 1.0 \\
\hline Chromium & 5.0 \\
\hline Lead & 5.0 \\
\hline Mercury & 0.2 \\
\hline Silver & 5.0 \\
\hline $\begin{array}{l}\text { a EPA has promulgated standards for other toxic } \\
\text { contaminants, but they are not listed here because they are } \\
\text { not found in batteries. }\end{array}$ \\
\hline
\end{tabular}

Nontoxic hazardous wastes, such as corrosive wastes, may be listed by name as a hazardous waste by the EPA or may be determined as hazardous by various EPA rules or test methods.

Lithium is considered a reactive material under EPA guidelines; hence, spent lithium EV batteries containing metallic lithium foils (e.g., in the negative electrode) would be considered a hazardous waste at the end of their life and would have to be managed and disposed of according to EPA hazardous waste regulations. However, as discussed previously in the section on battery safety, no information is available on the reactivity of the various nonmetallic lithium compounds being used in the development of lithium SPE batteries. Although it is thought that these materials would still be considered hazardous by the EPA (because they contain lithium), testing should be conducted in the future to determine if they would be considered reactive. For reference, a general EPA definition of a reactive waste is given below.

Reactivity. Properties defining reactivity include a substance that 1) reacts violently with water, 2) forms potentially explosive mixtures with water, 3) when mixed with water, generates toxic gases, vapors, or fumes in a quantity sufficient to present a danger to human health or the environment, or 4) is a cyanide or sulfide bearing 
waste which, when exposed to $\mathrm{pH}$ conditions between 2 and 12.5, can generate toxic gases, vapors, or fumes in a quantity sufficient to present a danger to human health or the environment ( 40 CFR 261.23). A solid waste that exhibits the characteristic of reactivity has the EPA hazardous waste number D003.

This assessment assumes that lithium is the primary material in the battery classified as hazardous by the EPA.

With respect to toxic substances in battery waste, it was not possible to conduct a complete analysis on the toxicity of the constituents because of the limited data available. However, partial evaluation showed that the only EPA toxic material listed in Table 3 found in SPE cells was arsenic in the LiAsF $_{6}$ electrolyte.

\section{Lithium Battery Treatment Facilities}

Three companies in North America dispose of lithium batteries, but none of them recycle the lithium in the batteries. Some of the battery materials, primarily the ferrous scrap from the battery cases, are reclaimed. Details of the processes are discussed below. There does not appear to be any significant lithium battery reclamation activities in Western Europe.

$B D T$, Inc.

BDT, Inc., located in Clarence, New York, processes spent consumer, industrial, and military lithium cells. BDT's facility is a permitted RCRA facility. This means that the facility has received a treatment, storage, and disposal permit from the EPA.

In the deactivation process outlined in Figure 2, the batteries are placed onto a conveyor, which feeds a hopper containing sodium hydroxide solution. The batteries and solution enter a hammermill, where they are breached and the lithium reacts with water, producing lithium hydroxide and hydrogen. The partially deactivated lithium materials and other fragmented battery materials enter a chemical holding tank, where the deactivation of lithium is completed. The battery materials are skimmed from the surface or the bottom of the tank and placed into drums for disposal. The solution is recycled, and, periodically removed and disposed of off-site. The process gases are vented to a wet scrubber, where the gases are treated with sodium hypochlorite before release (Guptill 1993). 


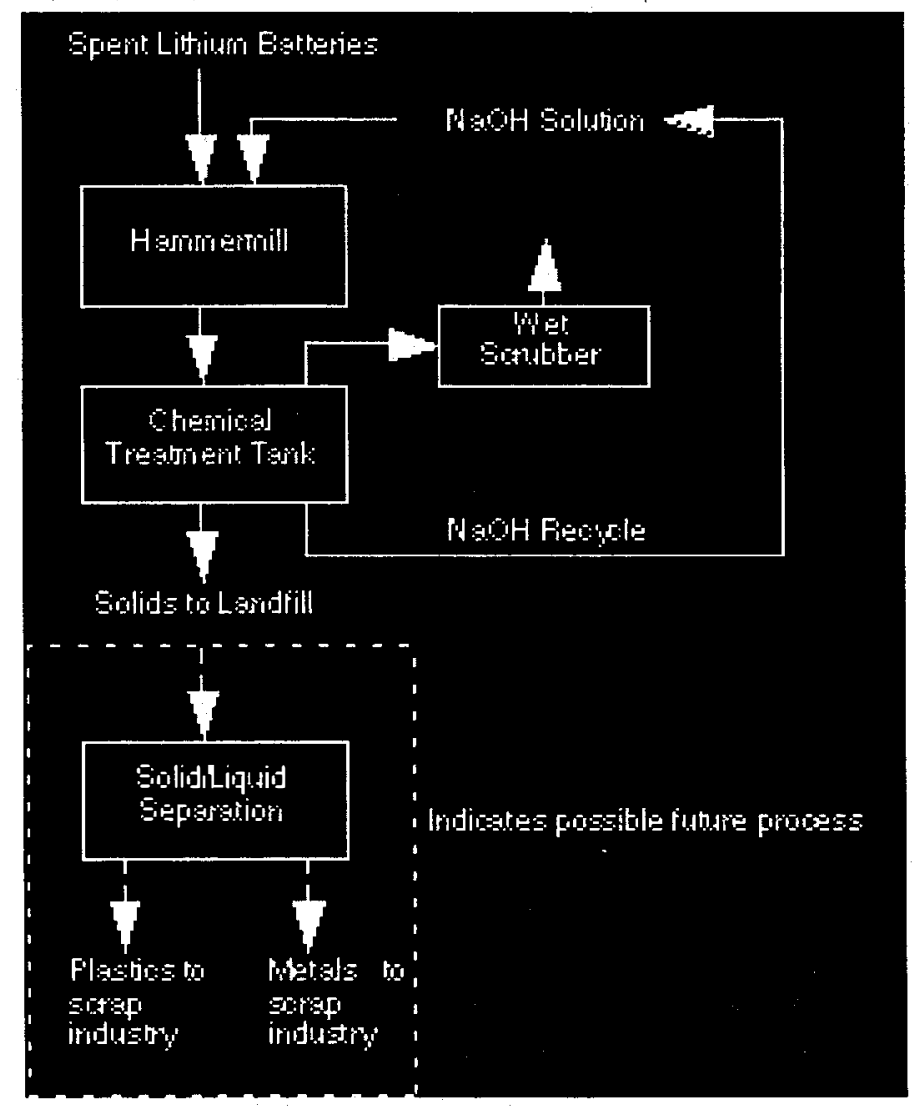

Figure 2. BDT, Inc., process for lithlum battery deactivation

BDT is investigating a recovery process for the metals and plastics from batteries that uses countercurrent wet classification. BDT also has evaluated the recovery of lithium salts from its process. Based on BDT research, it appears that lithium recovery is not economically viable at BDT's location (Guptill 1993, 1994). Currently, BDT does not reclaim any of the battery materials. 


\section{Recovery and Reclamation, Inc.}

Recovery and Reclamation, Inc., (R\&R) is a battery recycling company in Pecos, Texas. $R \& R$ specializes in the separation of zinc carbon, zinc chloride, alkaline manganese, and lithium batteries. $\mathrm{R} \& \mathrm{R}$ uses a four-step process to separate the battery components.

The $R \& R$ process uses physical separation procedures for recycling segregated battery streams. Lithium batteries are discharged to reduce the quantity of lithium metal available, and placed into a hopper, which feeds into a shredder. Batteries are shredded under potassium hydroxide solution and directed onto a conveyor that feeds into an indirectly fired double-shell rotary dryer. The rotary dryer drives off the water from the shredded batteries. The dried material is introduced into an air classifier which separates the material into two fractions: steel and carbonaceous materials. A flowsheet of the process is shown in Figure 3.

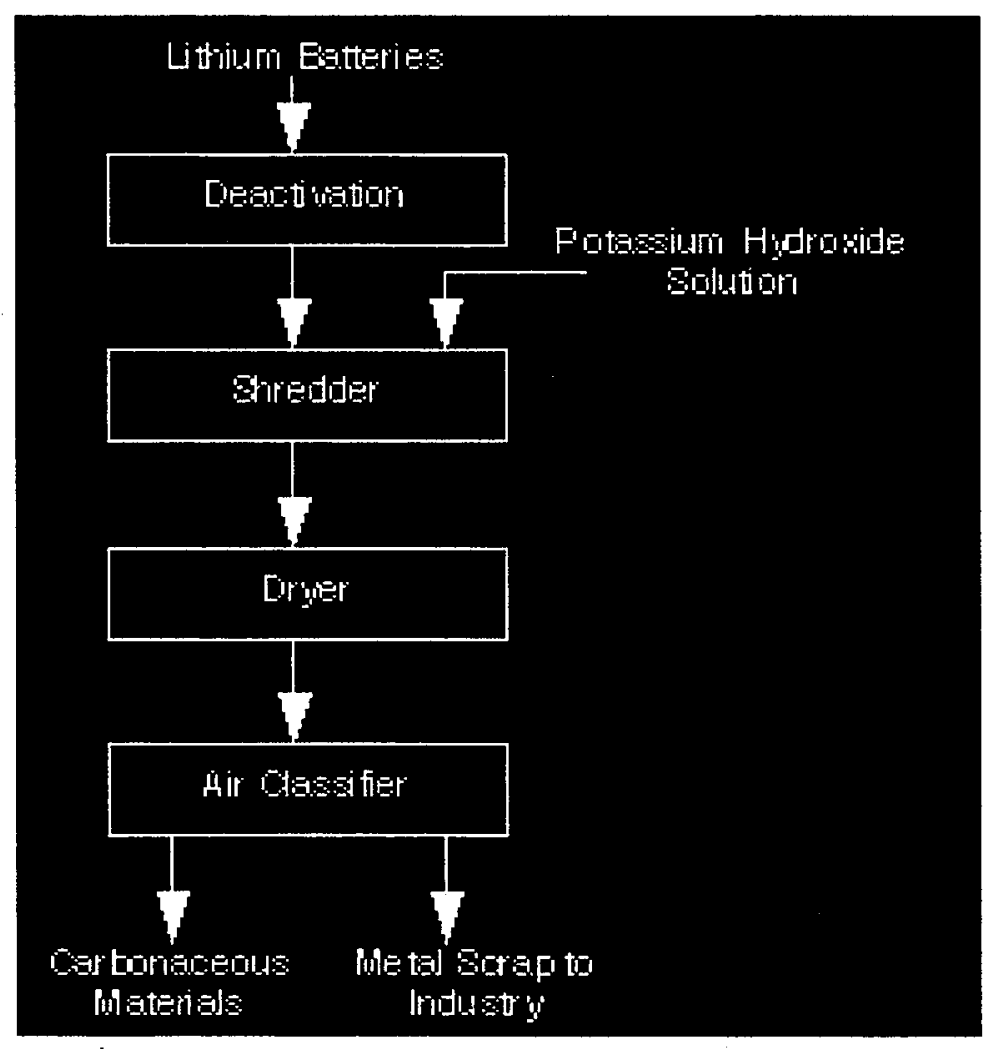

Figure 3. Recovery and Reclamation, Inc., process for separating components of lithlum batteries 
The R\&R plant processed approximately 100 tons (91 metric tons) of lithium batteries in 1993. $\mathrm{R} \& \mathrm{R}$ claims to have conducted demonstration tests on the deactivation of large lithium cells, including Minuteman batteries (A.D. Little 1994).

Toxco, Inc.

Toxco, Inc., is a lithium battery neutralization, disposal, and reclamation company located in Trail, British Columbia. Toxco is a permitted storage facility. According to Toxco representatives, the U.S. EPA and the U.S. Department of Defense have approved Toxco for the disposal of lithium waste (McLaughlin 1993). Toxco is processing lithium thermal and lithium thionyl chloride batteries.

In the Toxco process, lithium batteries are first cooled with liquid argon to reduce the reactivity of the lithium. The batteries are then shredded, and the lithium is deactivated in an aqueous solution. Then the battery materials are separated into various component streams for possible recycling. Toxco is focusing on the decommissioning of large military batteries (McLaughlin 1993).

\section{Deactivation of Lithium Metal}

Hydrolysis technology is based on the fact that water, under controlled conditions, modifies certain reactive chemical elements and compounds safely. Furthermore, the resultant species can be handled safely (i.e., it is no longer reactive).

In the three processes described previously, deactivation of lithium metal is achieved through hydrolysis. Lithium is reacted with a basic solution of sodium or potassium hydroxide. The lithium forms lithium hydroxide, and hydrogen evolves from the solution. In the case of BDT and R\&R, the batteries are shredded at room temperature; in the case of Toxco, the shredding is done cryogenically followed by deactivation. In either case, the deactivation is done with water to produce lithium hydroxide.

\section{Deactivation, Recycling, and Reclamation of Lithium SPE Batteries}

The preferred method for battery disposal at the end of life is recycling. The main reasons for recycling are environmental protection, waste reduction, and conservation. However, basic conditions must be met in order for recycling to be economical, environmentally safe, and practical. These conditions include (1) a sufficient quantity of spent batteries for recycling, (2) a high enough concentration of recyclable materials so that they can be reused/reclaimed, (3) a market for the recovered materials, and (4) the availability of a treatment process with justifiable energy requirements and low environmental impacts (e.g., low emissions and process residues).

As previously mentioned, current disposal processes for lithium batteries rely on hydrolysis to deactivate the lithium. The solids resulting from the battery treatment process are normally nonRCRA regulated wastes and are usually disposed of in a landfill. However, the metal and plastic from the process, which comprise the majority of the solids, may be recycled (Guptill 1993). Waste 
liquids generated by hydrolysis of batteries consist primarily of water and inorganic electrolytes and may be treated as necessary, then discharged. Lithium is the only component of the waste liquid that could have sufficient value for consideration as a recoverable material. However, there is currently no economic incentive for the recovery of lithium (Guptill 1993). This could change based on the availability of large amounts of lithium materials for recycling, the cost of lithium on the open market, environmental regulations governing recycling, and other related factors.

Because of the very low quantity of lithium in a battery, estimated previously to be in the range of $5 \mathrm{~kg}$ for a $25-\mathrm{kWh}$ battery, it is unlikely that lithium recovery options for lithium SPE systems currently would be economically viable. However, the bulk of a lithium SPE EV battery will be composed of metals (e.g., stainless steel) and plastics, and many of these materials may be recycled.

Finally, this discussion on lithium battery recycling has assumed that metallic lithium, as used in the lithium battery types currently being recycled, would be used in lithium SPE systems. However, for many types of lithium SPE batteries, no metallic lithium would be used in the cells; instead, lithium in its ionic form would be present (e.g., lithium intercalated carbons - see the chapter on lithium cell and battery safety for a discussion of lithium SPE materials). The reactivity of nonmetallic lithium compounds would be different than that of metallic lithium, and this would affect the feasibility of using hydrolysis to deactivate lithium SPE cells. This, in turn, could have a large effect on the feasibility and economics of recycling lithium SPE cells with nonmetallic lithium electrodes. 


\section{Shipping Requirements for Lithium SPE Batteries}

\section{General Information and Scope}

This section examines the shipping regulations that govern the transportation of lithium SPE batteries and cells. It is assumed that both metallic and intercalated carbon negative electrode designs fall within the purview of these regulations. To perform such an assessment, the hazards that these batteries or cells may pose in transportation are reviewed. Regulations exist at both the domestic and international levels that prescribe requirements for shipping any substance or article that is considered to be a "hazardous material" according to "hazard class" definitions established in those regulations. It is important to note that the term "hazardous material" is normally employed in U. S. domestic regulations, whereas the term used in most international regulatory standards to describe such materials is "dangerous goods."

Whether or not a substance is considered "hazardous" depends on attributes such as flammability and potential to produce heat. Substances that, when in contact with water, may become spontaneously flammable or evolve dangerous quantities of flammable gas are generally considered to pose an unreasonable risk to health, safety, and property when transported in commerce. Consequently, the hazard classification scheme in both the domestic and international systems includes a specific "hazard class" into which substances posing this hazard characteristic must be "classified" for purposes of transport. As a result, materials (such as lithium and lithium alloys) that exhibit this characteristic are, by definition, considered hazardous in transport and made subject to applicable regulations. In addition, batteries and cells containing lithium or lithium alloys may contain additional substances that meet the definition of other hazard classes regulated in transport (e.g., oxidizers or poisons), and may also present a hazard resulting from stored energy that could, under certain conditions, generate dangerous quantities of heat.

In connection with the general obligations placed by these standards on persons offering hazardous materials for transport, it is important to note that the DOT hazardous materials regulations, and various international regulations, contain specific requirements for the training of all individuals who are in any way involved with transporting hazardous materials. These include, but are not limited to, persons involved in the classification of hazardous materials, packaging, marking, labeling, preparation of shipping papers, and any other preparation of a consignment for shipment. Both initial and recurrent training is required, which must consist of both general awareness training and "function specific" training. Employers must maintain written records of this training, which are subject to inspection by DOT enforcement officers at any time.

This assessment assumes that persons engaged in the transport of lithium SPE cells and batteries will receive the required training and will maintain the appropriate records. In addition, because of the infancy of the lithium SPE battery technology, the design of the cells and batteries, as well as the materials contained therein, is subject to change. For these reasons, no attempt is made to address all details of the regulations applying to the transport of these devices. Instead, this assessment will focus on the more general regulatory requirements, with particular emphasis on the types and sizes of lithium SPE cells and batteries permitted for transport, the tests that such cells and batteries must 
be subjected to in order to qualify for transport, and steps that must be taken to permit the transport of cells and batteries not conforming to these quantity limitations and test requirements.

\section{Overview of Transportation Regulations}

Even though the details of the various international and domestic regulatory standards may differ in certain respects, the basic principles and measures employed to ensure transport safety are the same. Certain common elements exist in each, including similar hazard class definitions pertaining to characteristic properties of materials considered to constitute a hazard in transport. As mentioned previously, the hazard class definitions are the mechanism used to identify those materials or articles that are subject to regulation in transport. When substances and articles meet one or more of these hazard class definitions, both domestic and international regulatory systems impose the following types of requirements on the person offering the material for transport and/or transporting the material:

1. Minimum packaging standards

2. Marking and labeling of packages to identify the substance or article contained therein and nature of the hazard of that substance or article

3. Inclusion of required information on transport documentation to identify the substance or article transported, its hazard, the quantity being shipped and, in some cases, the steps to take in the event of an incident involving the material

4. Certification signed by the person offering the goods for transport stating that all applicable requirements have been fulfilled

5. Depending on the mode of transport involved (i.e., rail, highway, vessel, aircraft), specific requirements for the loading, handling, and carriage of the goods (e.g., identification of vehicles containing dangerous goods, segregation of incompatible goods, and so forth).

\section{United Nations Recommendations}

To promote uniformity in transport requirements for dangerous goods at the global level and among the various modes of transport, recommendations are developed by the United Nations (UN) Committee of Experts on the Transport of Dangerous Goods. These recommendations are published in a two-volume set entitled Recommendations on the Transport of Dangerous Goods (commonly referred to as "the UN Recommendations" or simply as the "Orange Book"—-the color of the cover). Because the UN Recommendations form the basis of not only the international air and sea transport requirements, but also of the domestic hazardous materials transport regulations, a description of the provisions concerning the transport of lithium batteries as presented in the UN Recommendations is a logical point to begin a discussion of lithium battery transport requirements in general. 
As previously mentioned, the UN Recommendations are published in two volumes. The first volume contains all basic transport provisions, including hazard class definitions; a listing of dangerous goods most commonly carried and the associated four-digit identification or "UN" number; package performance testing and certification requirements; and hazard communication requirements (e.g., labeling, marking, description, certification on transport documents, and so forth). The second volume, entitled Recommendations on the Transport of Dangerous Goods -Tests and Criteria, mainly deals with determination of the potential hazards posed by materials in transport and prescribes specific test methods and criteria to be used for the classification of goods for purposes of application of transport regulations. The most current edition of the UN Recommendations is the Eighth Revised Edition published in 1993. It reflects the recommendations as amended by the UN Committee of Experts at its most recent meeting, in December 1992.

At its December 1992 meeting, the UN Committee of Experts adopted major modifications to its provisions for the transport of batteries and cells containing lithium or lithium alloys. These revisions are promulgated in the Eighth Revised Edition of the UN Recommendations, and they are the basis for this discussion of the applicable transport requirements. This review will concentrate on the conditions under which such batteries and cells are generally considered acceptable for transport in accordance with the revised UN Recommendations.

Determination of whether or not a battery or cell is acceptable for transport under the UN Recommendations is a crucial issue since all domestic and international regulations are based on them. When a particular battery or cell does not conform to these requirements, the only available mechanism under which the battery or cell may be transported involves a case-by-case review process, or an approval by the regulatory authority concerned. While special administrative approval may be a workable solution for transporting within a single country, approval by all countries concerned with international shipment (i.e., countries of origin, transit, and destination) may prove to be impracticable because of the administrative burden.

The List of Dangerous Goods Most Commonly Carried, presented in Chapter 2 of the UN Recommendations, contains a specific entry for "LITHIUM BATTERIES" to which the identification number "UN 3090" is assigned. ${ }^{1}$ While the hazard presented by lithium and lithium alloys is typically that of a propensity to evolve flammable gas (hydrogen) on contact with water-a hazard identified within the UN classification system through classification of the substance or article concerned in Hazard Class 4.3-the UN Committee of Experts has nevertheless elected to assign a Class 9 hazard classification to lithium batteries. Under the UN classification system, Class 9 is a hazard class reserved for goods presenting "miscellaneous" hazards in transport. (That means it is a hazard not falling within the definition of any other hazard class (e.g., flammable, corrosive, explosive, capable of reacting dangerously with water, etc.). Lithium batteries have been classified by the UN in Class 9 more or less as a matter of convenience because certain batteries and cells may, in addition to lithium or lithium alloy, contain hazardous materials meeting the definitions of hazard classes other than Class 4.3, as well as electrical, reactive, or thermal hazards that various types of

1 For purposes of transport, this entry covers cells containing lithium or lithium alloys as well as batteries. 
lithium batteries may pose under certain conditions.

Thus, the "LITHIUM BATTERY" entry in the List of Dangerous Goods and the associated transport provisions treat such batteries and cells as "articles" containing hazardous materials, rather than as hazardous material transported in "substance" form. The only condition that a battery or cell must satisfy to be eligible to be transported under this entry is that it contain lithium or a lithium alloy. The presence of other hazardous materials does not preclude the use of this entry, or alter the transport conditions that would be applicable under the entry. Consequently, an advantage of transporting lithium SPE batteries and cells as articles under the lithium battery entry is that it is not necessary to specifically determine whether other materials in the battery or cell meet the definition of a hazardous material, or to take into account such additional hazardous materials, in the determination of the appropriate entry in the List of Dangerous Goods.

Associated with this entry are two Special Provisions that set forth the basic transport requirements for lithium batteries and cells. The first of these provisions (identified in the UN Recommendations as Special Provision 188) provides an "exception" for certain small batteries and cells. In other words, small batteries and cells meeting the conditions and limitations specified in Special Provision 188 are not considered to present a significant hazard in transport and are, therefore, declared not to be subject to regulation in transport. In order to be eligible for an exception from regulation under this special provision, no cell may contain more than $5 \mathrm{~g}$ of lithium or lithium alloy and no battery may contain more than $25 \mathrm{~g}$ of lithium or lithium alloy. In light of the relatively small quantities of lithium or lithium alloys permitted under this exception, batteries and cells used in EV applications generally would not be candidates for an exception from regulation based on these provisions.

The second special provision (identified as Special Provision 230), provides the basic criteria for determining whether a battery or cell is acceptable for transport under the lithium battery entry (UN 3090) in the UN Recommendations. Batteries and cells not meeting these criteria may be transported only when specifically approved by the transport regulatory agency of the country(ies) in which the batteries or cells will be transported. In addition to providing basic requirements regarding the design and arrangement of batteries and cells, Special Provision 230 also prescribes the basic packaging requirements for batteries and cells. UN Special Provision 230 is reproduced in Appendix B.

In Appendix B, attention is drawn to paragraphs (a) and (b) of Special Provision 230, which limit the amount of lithium or a lithium alloy that may be contained in a cell or battery to $12 \mathrm{~g}$ and $500 \mathrm{~g}$, respectively. Furthermore, note that in addition to the conditions and limitations presented in Special Provision 230, reference is made to the need to pass additional tests as prescribed in Part IV of the Recommendations on the Transport of Dangerous Goods, Tests and Criteria (specifically in Section 2 of Part IV). Section 2 of Part IV of the Tests and Criteria manual is reproduced in Appendix C.

Cells and batteries intended for EV applications may be capable of meeting the majority of the requirements presented in Special Provision 230 and of passing the relevant tests as prescribed in Part IV of the Tests and Criteria manual. However, two specific conditions in this special provision 
are of concern. The first relates to the lithium or lithium alloy quantity limitations provided in paragraphs (a) and (b). Because the quantity of lithium or lithium alloy contained in batteries and cells intended for EV applications would, in all probability, exceed the specified maximums, transport of cells and batteries in full conformance with the UN provisions may be precluded.

In addition, paragraph (j) of Special Provision 230 requires that ten cells and one battery "of each type taken from production each week" be subjected to thermal stability and short-circuit tests. The specified testing frequency was clearly developed with relatively small batteries and cells that are being produced in large quantities in mind. In the case of EV lithium SPE batteries and cells-both during development stages and, in the case of large, expensive batteries, during commercial production - testing at these frequencies may be prohibitive. Therefore, in light of the quantities of lithium or a lithium alloy contained in the cells and batteries, as well as on the basis of the required testing frequency, batteries and cells for EV applications generally may not be able to conform in all respects to the existing $\mathrm{UN}$ provisions.

Those batteries that meet all of the conditions and limitations prescribed in Special Provision 230 and pass the relevant tests as prescribed in Part IV of the Tests and Criteria manual, would be authorized for transport under the UN provisions. Such transport would, of course, be subject to compliance with all other applicable requirements, and so far including packaging, package marking, labeling, and transport documentation.

\section{Domestic Transportation Requirements}

The offering for transportation and transportation of hazardous materials within the U. S. - either for purely domestic transport or for international transport-is governed by DOT hazardous materials regulations. These regulations are codified in Title 49 of the Code of Federal Regulations, Parts 100 to 180 , and apply to transportation within the United States, including its territorial waters and airspace, by any mode of transportation-highway, rail, vessel, or aircraft. Under these regulations, a hazardous material is defined as any "substance or material...which has been determined by the Secretary of Transportation to be capable of posing an unreasonable risk to health, safety, and property when transported in commerce...."

Before any chemical, device (including any type of battery), or any other product may be offered for transport or transported in the United States (either for purely domestic shipment for international shipment), the person offering the material or device for transportation must determine that it does not pose an inherently unacceptable risk in transport. Materials posing such risks are referred to as "forbidden" materials in the DOT regulations. Section 173.21 of the DOT regulations provides a qualitative description of the types of materials considered to pose such inherent risks in transport as to be forbidden from transport altogether. 
Included as forbidden materials are:

1. Electrical devices that are likely to create sparks or generate a dangerous quantity of heat, unless packaged in a manner that precludes such an occurrence

2. Packages that give off flammable gas or vapor released from a material not otherwise considered a hazardous material ${ }^{2}$ that is likely to create a flammable mixture with air in a transport vehicle.

Therefore, batteries posing such inherent risks (as packaged for transport) would be unacceptable for transport. Examples would include charged batteries where short circuits could result in the generation of dangerous quantities of heat, unless packaged to prevent such an occurrence (such as by protecting terminals from short circuit), or batteries capable of evolving dangerous quantities of flammable gases. No quantitative criteria are provided in the regulations to define "dangerous" quantities of heat or gas, so it is necessary that a subjective judgement be made based on the packaging and manner in which the batteries are prepared for transport, and the conditions likely to be encountered in transport.

Provided that a lithium SPE battery or cell has been determined not to be a "forbidden material," the battery or cell may be offered for transport, and transported, provided all applicable requirements of the DOT regulations are satisfied, as discussed below. Batteries or cells not meeting these requirements may only be transported under an approval issued by the DOT.

Like the UN Recommendations, the Hazardous Materials Table in the current DOT regulations contains a listing for "LITHIUM BATTERIES," classed in Class 9, to which the identification number "UN 3090" is assigned. ${ }^{3}$ Also like the UN Recommendations, regulatory exceptions are provided for "small" lithium batteries. However, under the DOT exception, cells or batteries containing more than $1 \mathrm{~g}$ or $2 \mathrm{~g}$, respectively, of lithium or a lithium alloy would not be candidates for exception. Therefore, for purposes of batteries intended for EV applications, this exception is considered to be irrelevant.

The basic conditions and limitations that determine whether a lithium battery or cell is acceptable for transport under the current DOT regulations are provided in Section 173.185. This section is reproduced in Appendix D. Specific attention is drawn to three provisions in $\S 173.185$ (as presented in Appendix D) that may be of particular significance in relation to the transport of

2 An example of a material that gives off flammable gas or vapor that is otherwise considered a hazardous material would be a flammable liquid (e.g., acetone). Because this material is considered a hazardous material on the basis of meeting the definition for Class 3 (flammable liquid), it is not a "forbidden material" as a result of its ability to give off flammable vapors.

3 The DOT regulations contain two separate entries for lithium batteries-one covering batteries and cells with liquid cathodes and the other covering batteries and cells with solid cathodes. Both entries are assigned the identification number "UN 3090." 
batteries or cells intended for use in EV applications. They are as follows:

1. The limitation in paragraph (a) in which it is stated that, notwithstanding the provisions in $\S 173.185$, rechargeable batteries and cells may only be transported with the specific approval of the DOT Associate Administrator for Hazardous Materials Safety

2. Paragraph (b), which limits to $12 \mathrm{~g}$ the quantity of lithium or lithium alloy that may be contained in any cell

3. Paragraph $(\mathrm{g})(1)$, which, for all practical purposes, limits the total quantity of lithium or lithium alloys that may be contained in any battery to $500 \mathrm{~g}$.

Batteries and cells meeting all of the conditions, limitations, and tests prescribed in $\S 173.185$ would be authorized for transport under the DOT regulations without specific approval by, or action on the part of, DOT. Transport of such batteries and cells would, of course, be subject to compliance with all other applicable requirements including packaging, package marking, labeling, transport documentation, and so forth.

However, as with rechargeable lithium batteries, batteries and cells not meeting the quantity limitations may only be transported with the specific approval of the DOT Associate Administrator for Hazardous Materials Safety (see $\S 173.185(\mathrm{~m})$ in Appendix D). Since it is anticipated that most, if not all, batteries and cells intended to be employed in EV applications will be rechargeable and/or will contain quantities of lithium or lithium alloys exceeding the limitations outlined above, such batteries will only be able to be transported with the specific written approval of the Associate Administrator. Such approval may also necessarily address alternative testing requirements and/or test frequencies to those prescribed in paragraphs $(h)(1)$ and $(h)(2)$, which may prove inappropriate for batteries or cells under development or for very large batteries such as may be used in EV applications, or any other provisions of $\S 173.185$ with which batteries or cells are unable to conform.

Additional requirements of the DOT regulations apply to the transport of lithium batteries by aircraft. For example, lithium batteries (liquid or solid cathode) are forbidden for transportation by passenger-carrying aircraft unless specifically approved by the Associate Administrator for Hazardous Materials Safety.

\section{International Sea and Air Transport Requirements}

The international requirements applicable to the transport of lithium (including lithium SPE batteries) by vessel are promulgated by the International Maritime Organization (IMO), and those applicable to intemational transport of such batteries by commercial aircraft are promulgated by the International Civil Aviation Organization (ICAO). The IMO is a specialized agency of the United Nations responsible for the development of standards and regulations to promote the safety of life and property at sea and to prevent pollution from ships. The IMO dangerous goods transport requirements are presented in a four-volume document entitled the International Maritime 
Dangerous Goods Code (or "the IMDG Code"). The requirements published by ICAO governing the international air transport of dangerous goods are known as the Technical Instructions for the Safe Transport of Dangerous Goods by Air (or "the Technical Instructions"). Each of these regulatory standards is based on the UN Recommendations, but may contain additional quantity limitations and/or packaging or handling requirements appropriate to the particular mode of transport concerned.

\section{IMDG Code Provisions}

The current IMDG Code provisions for the transport of lithium batteries and cells, including the tests required to determine acceptability of batteries and cells for transport under those provisions, are essentially the same as the requirements in the current DOT regulations (as presented in $\S 173.185$, see Appendix D). However, unlike the DOT regulations, the IMDG Code provisions do not draw any distinction between rechargeable and primary batteries. Therefore, rechargeable batteries meeting all applicable requirements are permitted for transport without special approval. While the IMDG Code generally limits the quantity of lithium or lithium alloy in any cell or package to $12 \mathrm{~g}$ and $500 \mathrm{~g}$, respectively (as in the DOT regulations), there is provision with competent authority approval to increase the quantity of lithium or a lithium alloy in a cell to $60 \mathrm{~g}$ - subject to a maximum quantity of $500 \mathrm{~g}$ per battery. Also with competent authority approval, the total quantity of lithium or a lithium alloy in any package may be increased to $2600 \mathrm{~g}$.

Because the IMDG Code is based on the UN Recommendations, IMO has developed amendments to the code to update the lithium battery provisions to align them with the corresponding provisions in the Eighth Revised Edition of the UN Recommendations. These amendments are scheduled to become effective beginning January 1, 1995. At that time, the IMDG Code provisions for lithium batteries will mirror those in the UN Recommendations (see previous discussion, and Appendix B and Appendix C).

\section{ICAO Technical Instructions}

The current provisions of the ICAO Technical Instructions regarding the transport of lithium batteries and cells, including the tests required to determine acceptability of batteries and cells for transport under those provisions, are essentially the same as the requirements in the current DOT regulations (as presented in $\S 173.185$, see Appendix D). Also like the DOT regulations, the ICAO Technical Instructions contain two separate entries for lithium batteries-one covering batteries and cells with liquid cathodes and the other covering batteries and cells with solid cathodes. Both of these entries are assigned the identification number "UN 3090." Unlike the DOT regulations, however, the ICAO Technical Instructions do not draw any distinction between rechargeable and primary batteries. Therefore, rechargeable batteries meeting all applicable requirements are permitted for transport without special approval.

Under the Technical Instructions, the types of batteries and cells, the quantity of lithium or lithium alloy that may be contained therein, and the maximum gross weight of any package containing batteries or cells, is dependent on the type of aircraft (i.e., passenger carrying or cargo-only aircraft) 
to be employed in the transport of the cell or battery. These limitations may be summarized as follows:

- Cells - Cells may not contain more than $3 \mathrm{~g}$ of lithium in order to be acceptable for transportation by passenger-carrying aircraft and more than $12 \mathrm{~g}$ of lithium to be acceptable for transportation by cargo-only aircraft.

- Batteries - Batteries may not contain more than $125 \mathrm{~g}$ of lithium in order to be acceptable for transportation by passenger-carrying aircraft and more than $500 \mathrm{~g}$ of lithium to be acceptable for transportation by cargo-only aircraft.

- Packages - Individual packages containing batteries or cells may not contain more than $125 \mathrm{~g}$ of lithium in order to be acceptable for transportation by passenger-carrying aircraft or more than $500 \mathrm{~g}$ of lithium to be acceptable for transportation by cargo-only aircraft. The maximum gross weight of any package permitted for transport by passenger-carrying aircraft is $5 \mathrm{~kg}$, and for cargo-only aircraft is $35 \mathrm{~kg}$. Packages containing liquid cathode lithium batteries are forbidden for transport by passenger-carrying aircraft.

Since the ICAO Technical Instructions are based on the UN Recommendations, ICAO has prepared amendments to the Technical Instructions to update the lithium battery provisions to align them with the corresponding provisions in the Eighth Revised Edition of the UN Recommendations. These amendments are scheduled to become effective beginning January 1, 1995. At that time, the ICAO provisions for lithium batteries will mirror those in the UN Recommendations. However, the types of batteries and cells, the quantity of lithium or a lithium alloy that may be contained therein, and the maximum gross weight of any package containing batteries or cells permitted for transportation by passenger-carrying or cargo-only aircraft will remain as indicated above.

\section{Conclusions}

Because the lithium SPE battery is a developing technology, exact chemistries and the associated constituents may be proprietary. Nevertheless, it is possible to assess the general transport requirements applicable to lithium SPE batteries and cells if they are considered to be "articles" transported under the "LITHIUM BATTERY" entry and associated transport provisions in the regulations. As such, any hazardous material other than lithium or a lithium alloy that may be present in the battery or cell need not be specifically taken into account to determine the requirements applicable to the device.

The quantity of lithium or a lithium alloy present in a battery or cell is a critical factor when considering the associated transport requirements. As discussed in the Domestic Transportation Requirements section, it is anticipated that most, if not all, batteries and cells intended to be employed in EV applications will contain quantities of lithium or lithium alloy exceeding the $12 \mathrm{~g}$ per cell and $500 \mathrm{~g}$ per battery weight limitations. In addition, it is assumed that lithium SPE batteries intended for EV application will also be rechargeable. Therefore, under the domestic regulations, such batteries will only be able to be transported with the specific written approval of 
the Associate Administrator. Such approval may also necessarily address alternative testing requirements and/or test frequencies to those prescribed in paragraphs $(h)(1)$ and $(h)(2)$, which may prove inappropriate for batteries or cells under development or for very large batteries such as may be used in EV applications, or any other provisions of $\S 173.185$ with which batteries or cells are unable to conform.

On the international level, the IMDG Code provides for a quantity increase of lithium or lithium alloy in a cell to $60 \mathrm{~g}$, subject to a maximum quantity of $500 \mathrm{~g}$ per battery, under competent authority approval. Also under competent authority approval, the total quantity of lithium or lithium alloy in any package may be increased to $2600 \mathrm{~g}$.

Under the ICAO Technical Instructions, the quantity of lithium or a lithium alloy, and the maximum gross weight of any package containing batteries or cells, is dependent on the type of aircraft (i.e., passenger carrying or cargo-only aircraft) used to transport the battery or cell. Cells may not contain more that $3 \mathrm{~g}$ of lithium on passenger-carrying aircraft or more than $12 \mathrm{~g}$ of lithium on cargo-only aircraft. Batteries may not contain more than $125 \mathrm{~g}$ of lithium for passenger-carrying aircraft or more than $500 \mathrm{~g}$ for cargo-only aircraft. Individual packages may not contain more than $125 \mathrm{~g}$ of lithium for passenger aircraft, and not more than $500 \mathrm{~g}$ on cargo-only aircraft. The transport of batteries or cells not conforming to these requirements for any reason is permitted only with the approval of the appropriate transport agency in each country concerned with the transport of the devices. These countries include not only the countries of origin, destination, and transit of the consignment, but also the countries overflown by aircraft carrying the consignment. 


\section{References}

Aaseth, J. and T. Norseth (1986). "Copper." In Handbook on the Toxicology of Metals. L. Friberg, G.F. Nordberg, and V.B. Vouk (eds.). Elsevier Science Publishing Co., Inc., New York.

Abraham, K.M. (1994). Personal communication. November 16.

American Conference of Governmental Industrial Hygienists, Inc. (ACGIH) (1986). Documentation of the Threshold Limit Values and Biological Exposure Indices. Fifth Edition. ACGIH, Cincinnati, $\mathrm{OH}$.

American Conference of Governmental Industrial Hygienists, Inc. (ACGIH). (1993/1994). Threshold Limit Values for Chemical Substances and Physical Agents and Biological Exposure Indices. ACGIH, Cincinnati, $\mathrm{OH}$.

A.D. Little (1994). Unpublished communication regarding safety issues for lithium SPE batteries.

Agency for Toxic Substances and Disease Registry (ATSDR) (1990). Toxicological Profile for Copper. U.S. Public Health Service. Atlanta, GA. February (Draft).

Archuleta, M.M. (1994). "Toxicity of Materials Used in the Manufacture of Lithium Batteries." Proceedings of the Seventh International Meeting on Lithium Batteries. Boston, MA, May 15-20.

Corbus, D. (1992). "Recycling of Electric Vehicle Batteries." Proceedings: Fourth International Battery Waste Management Seminar. Deerfield Beach, Florida, November.

Corbus, D. (1992a). Environmental, Health, and Safety Issues of Sodium-Sulfur Batteries for Electric and Hybrid Vehicles, Volume II: Battery Recycling and Disposal. National Renewable Energy Laboratory, Golden, CO, NREL/TP-262-4680, September.

Dialog Information Services (1994). Toxline. MEDLARS Management Section, National Library of Medicine, Bethesda, MD.

Doddapaneni, N. (1991). Technology Assessment of Ambient Temperature Rechargeable Lithium Batteries for Electric Vehicle Applications. SAND91-0938 UC-212. Sandia National Laboratories, Albuquerque, NM, July.

Doll, R. (1991). Report of the International Committee on Nickel Carcinogenesis in Man. U.S. EPA Health Effects Research Lab, NTIS/PB91-109801, Research Triangle Park, NC.

European Chemical Industry Ecology and Toxicology Centre (ECIETC) (1989). Nickel and Nickel Compounds: Review of Toxicology and Epidemiology with Special Reference to Carcinogenesis. ECIETC, Bruxelles, Belgium, February. 
Fauteux, D., J.R. Powell, M.F. Van Buren, A. Massucco, P. McCabe, and B. Barnett (1993). "Properties, Performance and Manufacturability of Plasticized Polymer Electrolytes for Lithium Rechargeable Batteries." Proceedings of the Eight Annual Battery Conference on Applications and Advances. California State University, Long Beach, CA, January 12-14.

Gosselin, R.E., R.P. Smith, and H.C. Hodge (1984). Clinical Toxicology of Commercial Products. Fifth Edition. Williams \& Wilkins, Baltimore, MD.

Guptill, J.P. (1993). "Disposal of Lithium Batteries and the Potential for Recycling of Lithium Battery Components." Presented at the Fifth International Seminar on Battery Waste Management, Deerfield Beach, Florida, November 1-3.

Guptill, J.P. (1994). Personal communications, January.

Haney, M. and J. Casler (1990). RCRA Handbook. ENSR Consulting and Engineering, Acton, MA, October.

Hazardous Substances Data Bank (HSDB) (1994). Maintained and operated by the National Library of Medicine Toxnet System. Bethesda, MD.

Hooper, A. (1989). "Polymer Electrolyte Lithium Batteries." Proceedings of the Symposium on Materials and Processes for Lithium Batteries. The Electrochemical Society, Pennington, NJ.

International Agency for Research on Cancer (IARC) (1992). IARC Monographs on the Evaluation of Carcinogenic Risks to Human. Volume 55. Solar and Ultraviolet Radiation (includes cumulative index of Monographs). World Health Organization. Lyons, France.

International Agency for Research on Cancer (IARC) (1979). IARC Monographs on the Evaluation of the Carcinogenic Risk of Chemicals to Humans. Volume 19. Some Monomers, Plastics and Synthetic Elastomers, and Acrolein. Lyons, France, February 7-13, 1978.

International Civil Aviation Organization (ICAO) (1993/1994). Technical Instructions for the Safe Transport of Dangerous Goods by Air. ICAO, Montreal, Canada.

International Maritime Organization (IMO) (1990). International Maritime Dangerous Goods Code. Consolidated Edition, as amended. IMO, London, England.

Kirk-Othmer Encyclopedia of Chemical Technology (1978). Vol. 14, 3rd Edition. John Wiley \& Sons, New York.

Klaassen, C.D., M.O Amdur, and J. Doull (1986). Casarett and Doull's Toxicology. Macmillan Publishing Company, New York.

Landgrebe, A.R. (1993). "Technology Transfer from the Electric and Hybrid Propulsion Program." 
Proceedings of the Annual Automotive Technology Development Contractor's Coordination Meeting 1992. Society of Automotive Engineers, Warrendale, PA, May.

Leuschner, J., H. Haschke, and G. Sturm (1994). "New Investigations on Acute Toxicities of Vanadium Oxides." Monatshefte für Chemie, 125:623.

Mark, J. (1992). Environmental, Health, and Safety Issues of Sodium-Sulfur Batteries for Electric and Hybrid Vehicles, Volume IV: In-Vehicle Safety, National Renewable Energy Laboratory, Golden, CO, NREL/TP-463-4952, November.

McLaughlin, W.J. (1993). "Lithium Recycling and Disposal Techniques." Presented at the Fifth International Seminar on Battery Waste Management, Deerfield Beach, Florida, November 1-3.

The Merck Index (1989). Eleventh Edition, S. Budavari, ed. Merck and Company, Rahway, NJ.

National Toxicology Program (NTP) 1993. Management Status Report. Produced from NTP Chemtrack System. Division of Toxicology Research and Testing, October 8.

National Institute Occupational Safety and Health/Occupational Safety and Health Administration (NIOSH/OSHA) (1981). Occupational Health Guidelines for Chemical Hazards. U.S. Department of Health and Human Services, Public Health Service. DHHS (NIOSH) Publication No. 81-123.

National Institute Occupational Safety and Health/Occupational Safety and Health Administration (NIOSH/OSHA) (1978). Pocket Guide to Chemical Hazards. U.S. Department of Health, Education, and Welfare. Public Health Service. DHEW (NIOSH) Publication No. 78-210.

North American Combustion Handbook (1978). R.J. Reed, ed. North American Manufacturing Company, Cleveland. Second Edition, 1st printing.

Occupational Safety and Health Administration (OSHA) (1993). 29 CFR, Part 1910-Occupational Safety and Health Standards (Continued). Subpart Z-Toxic and Hazardous Substances.

Owens, B.B. and Douglas, D.L. (1991). "Ambient Temperature Lithium Batteries for Electric Utility and Vehicle Applications." Proceedings of the Symposium on Primary and Secondary Ambient Temperature Lithium Batteries. The Electrochemical Society, Pennington, NJ.

Patty's Industrial Hygiene and Toxicology (1981). G.D. Clayton and F.E. Clayton, eds. John Wiley \& Sons, Inc., New York.

Registry of Toxic Effects of Chemical Substances, 1985-1986 Edition (RTECS) (1987). D.V. Sweet, ed. U.S. Department of Health and Human Services, Public Health Service, National Institute for Occupational Safety and Health, April.

Society for Automotive Engineers (SAE) (1986). Storage Batteries, SAE J537. 
Sax, N.I., and R.J. Lewis (1989). Dangerous Properties of Industrial Materials. Seventh Edition. Volumes I, II, and III. Van Nostrand Reinhold, New York.

Scrosati, B. (1993). "A Critique of Lithium Polymer Battery R\&D." Presented at the Tenth International Seminar on Primary and Secondary Battery Technology and Application. Florida Education Seminars, Boca Raton, FL, March.

Sittig, M. (1985). Handbook of Toxic and Hazardous Chemical and Carcinogens. Second Edition. Noyes Publications, Park Ridge, NJ.

STN International (1994). On-line Registry file. Chemical Abstracts Service, Columbus, OH.

United Nations (1990). Recommendations in the Transport of Dangerous Goods, Tests and Criteria. Second Edition. United Nations, New York.

U.S. Department of Transportation (DOT) (1990). Emergency Response Guidebook, DOT P5800.5, U.S. Department of Transportation, Washington, D.C.

U.S. Department of Transportation (DOT) (1993). 49 CFR Parts 100-180. Hazardous Materials Regulations.

U.S. Environmental Protection Agency (EPA) (1984). Health Effects Assessment for Manganese (and compounds). Environmental Criteria and Assessment Office, Cincinnati, OH. Final Draft. September.

U.S. Environmental Protection Agency (EPA) (1990) 40 CFR Part 148. Land Disposal Restrictions for Third Scheduled Wastes. Final Rule, Federal Register, June 1.

U.S. Environmental Protection Agency (EPA) (1994). Integrated Risk Information System. Office of Health and Environmental Assessment, Washington, DC. 


\section{Appendix A}

\section{Toxicity Summaries for Potential Lithium Polymer Battery Constituents}

\section{Aluminum}

The insoluble forms of aluminum produce no measurable acute response (Patty's 1986). Acute aluminum toxicity in humans is unlikely (HSDB 1994).

Reports of the toxicity of aluminum are related to: (1) effects on the gastrointestinal tract; (2) effects via inhalation of aluminum compounds; and (3) systemic toxicity of aluminum. Aluminum compounds can affect the absorption of other elements in the gastrointestinal (GI) tract and alter intestinal function. Pulmonary effects of aluminum occur following inhalation of fumes during extraction from bauxite. There is a possible role of aluminum in the development of dementia in humans. Animals studies have found exposure to aluminum produces a progressive neurological decline similar to that found in Alzheimer's disease. Similar symptoms have been reported in dialysis patients (Klaassen, et al. 1986). Other effects in dialysis patients may include liver failure, encephalopathy, and microcytic anemia (HSDB 1994).

The knowledge of the acute toxicity of aluminum is limited to results from animal studies with the more soluble forms, the chlorides and sulfates. Sulfates were considerably more toxic. Acute poisoning resulted in increased blood glucose, decreased liver glycogen, and increased incorporation of phosphorous in the liver. One of the most acutely toxic aluminum-containing compounds is the phosphide.

Aluminum production industries report cases of pulmonary fibrosis and emphysema resulting from exposure to metallic aluminum dust. Some epidemiologic evidence suggests that additives to aluminum products may affect the incidence and perhaps the character of the disease. Fumes from aluminum soldering flux have been reported to result in a delayed type of asthma (Patty's 1986).

Aluminum dust may cause eye irritation. Aluminum contact with skin has been associated with delayed hypersensitivity and other skin effects (HSDB 1994). For example, repeated contact of the skin with the soluble salts of aluminum results in acid irritation from hydrolysis (Patty's 1986).

Neither IARC nor NTP have investigated aluminum as a potential carcinogen (IARC 1992; NTP 1993). 


\section{Carbon}

Quantitative toxicity information for carbon is limited to experimental animals. It is moderately toxic by the intravenous route, and has been found to have reproductive effects in experimental studies. Carbon can cause a dust irritation in experimental animals, particularly to the eyes and mucous membranes (Sax and Lewis 1989). Carbon has not been investigated by IARC or NTP for carcinogenicity (IARC 1992; NTP 1993).

\section{Copper}

Reports of copper toxicity involve the consumption of contaminated water with high levels of copper, attempts of suicide using copper sulfate, or industrial exposure by inhalation of copper fumes.

The primary toxicological effect following accidental ingestion of large amounts of copper salts, about 15 to 75 milligrams of copper, is GI irritation. This is manifested as vomiting, nausea, diarrhea, and loss of appetite. Systemic effects, especially hemolysis, liver damage, and kidney damage have been reported after ingestion of large amounts of copper salts (ATSDR 1990; HSDB 1994).

Copper is an essential element. The estimated daily requirement for adults is 2 milligrams or about 0.03 milligrams $/ \mathrm{kilogram}(\mathrm{mg} / \mathrm{kg})$ of body weight, $0.04 \mathrm{mg} / \mathrm{kg}$ for older children, and $0.08 \mathrm{mg} / \mathrm{kg}$ of body weight for infants. Daily intake of copper from food varies from 0.02 to $0.05 \mathrm{mg} / \mathrm{kg}$ of body weight in adults (Aaseth and Norseth 1986).

Inhalation of copper fumes causes irritation of the respiratory tract and "metal fume fever." Metal fume fever is an influenza-like syndrome with symptoms that disappear after 24 hours. Centrolobular necrosis of the liver and sloughing of tubular cells in the kidney as well as necrosis have been observed in individuals suffering from copper poisoning.

While exposure to copper is common in industry, chronic effects due solely to copper have not been documented. There is no positive correlation between chronic copper exposure and cancer. Chronic copper poisoning has not been described in normal human beings (Aaseth and Norseth 1986). Individuals with Wilson's disease typify chronic copper poisoning with symptoms that include hepatic cirrhosis, brain damage and destruction or loss of the myelin sheath of a nerve or nerves, kidney defects, and copper deposition in the cornea (Patty's 1981).

Skin exposure to copper dust may result in severe irritation and discoloration of the skin (HSDB 1994). Upon contact, copper salts such as copper sulfate, copper chloride, copper acetate, and copper nitrate, act as irritants with itching, redness and skin inflammation (Sittig 1985). Itching inflammation of the skin occurs in some individuals exposed to copper metal. Allergic contact dermatitis has been observed in individuals following a patch test using a copper penny or copper sulfate solution (ATSDR 1990). Mucosal irritation of the eyes has been reported in factory workers exposed to copper dust. Copper salts may cause conjunctivitis and ulceration and turbidity of the 
cornea upon contact (Sittig 1985).

There are no human data and inadequate animal data from assays with copper compounds as to its carcinogenicity (U.S. EPA 1994). There is no proof of a positive correlation between copper exposure and cancer. The increased incidence of lung cancer reported among workers in copper refineries and copper-ore mines has been considered an effect of arsenic contamination. Some copper compounds seem to have an inhibitory effect on the development and growth of malignant tumor cells (Aaseth and Norseth 1986).

There are no data on the mutagenicity of copper in humans. Equivocal mutagenicity data exists for copper (U.S. EPA 1994). In vivo studies and mammalian system in vitro studies suggest that copper is a potential weak mutagen.

Elemental copper has not been studied for carcinogenicity by either IARC or the NTP (IARC 1992; NTP 1993).

\section{Dimethyl Carbonate}

In animal tests, this compound is moderately toxic by the intraperitoneal route, and is mildly toxic by ingestion (Sax and Lewis 1989). Dermal experiments resulted in some weight loss. Minimal skin absorption was suspected, and the degree of irritation was relatively slight. Exposure by inhalation in experimental animals was hazardous, since $8000 \mathrm{ppm}$ caused rapid onset of gasping, loss of coordination, and pulmonary edema, followed by death in a period of 2 hours (Patty's 1981). No human toxicity data were identified for this compound. Dimethyl carbonate has not been investigated for carcinogenicity by IARC or NTP (IARC 1992; NTP 1993).

\section{Dimethyl Ether}

The principal physiological effect of dimethyl ether is anesthesia. In animals, atmospheric concentrations of $0.02,0.2$ and 2 percent dimethyl ether were evaluated. No adverse effects were seen on body weight, food consumption, hematology, urinalysis or histopathology. Some results suggested liver toxicity (Patty's 1981). No human toxicity data were identified for this compound. Dimethyl ether has not been investigated for carcinogenicity by IARC or NTP (IARC 1992; NTP 1993).

\section{Ethylene Carbonate}

Ethylene carbonate is moderately toxic by the intraperitoneal route in animals. In animals, it is mildly toxic by ingestion, and a skin and eye irritant (Sax and Lewis 1989). Inhalation of the concentrated vapor for 8 hours was not lethal to rats. The undiluted material was slightly irritant to rabbit skin and moderately irritant to the rabbit eye (Patty's 1981). No human toxicity data were identified for this compound. Ethylene carbonate has not been investigated for carcinogenicity by IARC or NTP (IARC 1992; NTP 1993). 


\section{Graphite}

Graphite is a soft crystalline form of carbon, and it can be natural or synthetic. Synthetic graphite is produced by heating a mixture of coal or petroleum coke, a binder (generally coal tar pitch), a petroleum-based oil, and in some cases, anthracite coal. Therefore, the characteristics depend on the quality of coke and binder, the degree of orientation of the particles during extrusion, and the temperature and time of processing. Graphites may be blended to obtain desired product characteristics. Because the specific composition of these products is often retained as a trade secret, it may not be possible to completely characterize the toxicity of a particular graphite (ACGIH 1986).

Animal studies have shown that coal and graphite produced similar mild fibrotic reactions when given to rats by intratracheal injection. There have been numerous reports of pneumoconiosis among workers exposed to graphite-containing dusts. They have included miners and millers, carbon electrode manufacturers, and molders. In the majority of cases, there are concurrent exposures to other fibrogenic dusts that are contained in the graphite dust (ACGIH 1986). Natural graphite may affect the eyes (NIOSH/OSHA 1978).

NTP has not conducted studies with natural or synthetic graphite; however, pitch-based, fibrous graphite has been nominated for toxicologic testing by the NTP (ACGIH 1986).

\section{Lithium and Lithium Compounds}

Information was requested for $\mathrm{Li}_{x} \mathrm{Mn}_{2} \mathrm{O}_{4}, \mathrm{Li}_{x} \mathrm{CoO}_{2}, \mathrm{LiPF}_{6}, \mathrm{LiBF}_{4}, \mathrm{LiCF}_{3} \mathrm{SO}_{3}$, and $\mathrm{LiN}\left(\mathrm{CF}_{3} \mathrm{SO}_{2}\right)_{2}$.

Little toxicology information was found for the specific lithium compounds listed. Much of the literature on lithium relates to the use of lithium carbonate as a medication for the treatment of depression. Industrial hygiene texts state that with the exception of lithium hydride, none of the other salts nor the metal itself is medically hazardous in industrial settings.

The toxicity of lithium is determined not only by the amount of lithium ingested, but by the amount of sodium intake: the lower the sodium intake, the more toxic are the effects of lithium. In experimental animals, the primary action of lithium is on kidney function. Lithium also has been found to be teratogenic in animals (Patty's 1981).

Much of the literature information on lithium relates to its use as a medication for the treatment of depression (lithium carbonate). The difference between therapeutic levels of lithium and toxic levels is small (therapeutic blood levels, 0.6 to $1.2 \mathrm{mEq} / \mathrm{L}$; toxic levels, mild to moderate, 1.5 to 2.5 $\mathrm{mEq} / \mathrm{L}$, severe 2.5 to $3 \mathrm{mEq} / \mathrm{L}$ ) (HSDB 1994). The initial effects of lithium exposure are tremors of the hands, nausea, micturition, slurred speech, sluggishness, sleepiness, vertigo, and thirst. Effects from continued exposure are apathy, anorexia, fatigue, lethargy, muscular weakness, and changes in ECG. Long-term exposure leads to hypothyroidism, leukocytosis, edema, weight gain, polydipsia/polyuria, memory impairment, seizures, kidney damage, cardiac arrhythmias, coma, and death. Lithium has also been implicated in the development of aplastic anemia (Sax and Lewis 
1989). The therapeutic use of lithium carbonate can produce neuromuscular changes, CNS changes, cardiovascular changes, gastrointestinal changes, and renal damage. This latter effect can occur with long-term exposure even when lithium levels remain in the therapeutic range (Klaassen, et al. 1986). Photophobia has been reported following chronic lithium intoxication (compound not identified), as have transitory blurred vision and blindness (HSDB 1994).

Lithium hydride is intensely corrosive and may produce burns because of the formation of hydroxides. It produces large amounts of hydrogen gas when exposed to water; this reaction can cause severe damage to exposed tissue (Sax and Lewis 1989).

Lithium oxide, hydroxide, carbonate, etc., are strong bases and their solutions in water are very caustic. Otherwise, toxicity of lithium compounds is a function of their solubility in water. The halide salts are highly soluble in water; the carbonate, phosphate, oxalate, and fluoride are relatively insoluble in water (Sax and Lewis 1989).

Lithium is a common metal and is present in many plant and animal tissues. Normal daily intake is about $2 \mathrm{mg}$. It is readily absorbed from the gastrointestinal tract. The greater part of lithium is contained in the cells. (Klaassen, et al. 1986).

Lithium and lithium compounds have not been investigated by IARC or NTP (IARC 1992; NTP 1993). No CAS number was found for $\mathrm{LiN}\left(\mathrm{CF}_{3} \mathrm{SO}_{2}\right)_{2}$.

\section{Lithium Hexafluoroarsenate}

Since no studies of lithium hexafluoroarsenate were reviewed, toxicological information about arsenic compounds is presented here. Please refer to the effects of lithium compounds as well.

Arsenic compounds enter the body through the lungs or the digestive system. Arsenic compounds vary in their toxicity and carcinogenicity. Industrial studies of human exposure have generally considered arsenic in its trivalent form. Lithium hexafluoroarsenate contains arsenic in its less toxic pentavalent form. Therefore, the findings regarding arsenic compounds presented here may not all apply.

Acute arsenic toxicity occurs due to inflammatory damage to the digestive system. In the case of a less than fatal dose, skin and nerve damage may persist after recovery from the most acute symptoms.

In addition to acute toxicity, chronic exposure to arsenic compounds can damage the skin, mucous membranes, peripheral nervous system, and blood. Most common among these effects are skin problems, such as acute and chronic dermatitis (Patty's 1981).

Arsenic is a Group 1 carcinogen, with sufficient evidence to document its carcinogenicity in humans (ACGIH 1993-1994). 


\section{Lithium Perchlorate}

Please refer to the effects of lithium compounds.

\section{Manganese Dioxide}

In general, there are more studies regarding the toxicity of manganese salts than for other manganese compounds. The following is a summary of toxicity information on manganese and manganese compounds.

Manganese exists in all valence states from -3 to +7 , with the $+2,+4$, and +7 states being dominant. Manganese is an essential trace element that appears to act as a cofactor in numerous enzyme reactions. The principal uses of manganese are in steel-making, battery manufacture, and the chemical industry (Patty's 1981).

The toxicity of manganese compounds varies with the specific chemical forms, with cationic species being more toxic than anionic species, divalent ions more toxic than trivalent ions, and high solubility species being more toxic than those with low solubility. Toxicity following acute ingestion of inorganic manganese salts is unlikely since they are poorly absorbed from the gastrointestinal tract. Systemic toxicity is mostly linked to chronic inhalation or ingestion; two clinical patterns are common, one involving the central nervous system, and the other a manganese pneumonia. Neurological changes are most frequently reported following chronic inhalation of manganese dusts in an industrial setting (HSDB 1994).

Experimental animal studies have indicated that exposure to small doses of manganese can induce a tolerance to higher subsequent exposures. Animal studies of manganese toxicity have also reported effects on liver function and depression of blood pressure (U.S. EPA 1984).

Manganese is classified as an EPA Group 4 Carcinogen. Data concerning human or animal carcinogenicity were not located in the available literature. Injection exposure studies in rodents using intramuscular, intraperitoneal, and subcutaneous injections have found no statistically significant increases in tumors following exposure to manganese dioxide, manganese powder, or manganese dichloride (U.S. EPA 1984).

Neither manganese nor manganese dioxide have been investigated for carcinogenicity by IARC or by NTP (IARC 1992; NTP 1993).

\section{Methyl Formate}

This compound is moderately toxic by ingestion in laboratory animals. Inhalation of vapor can cause irritation to nasal passages and conjunctiva, optic neuritis, narcosis, nausea, and death from pulmonary irritation. Industrial fatalities have occurred only with exposure to high concentrations (Sax and Lewis 1989). Occupational effects involved visual disturbances, irritation of mucous membranes and dyspnea. However, since methyl formate is most commonly employed as a 
component of solvent mixtures, it is difficult to determine the exact symptomatology of this compound (HSDB 1994). Neither IARC nor NTP has investigated the carcinogenicity of methyl formate (IARC 1992; NTP 1993).

\section{Nickel Oxide}

Acute nickel poisoning occurs due to digestive tract and nervous system symptoms, with heart failure the usual cause of death in animals. In humans, acute toxicity is rare, but chronic exposure to nickel causes dermatitis and respiratory cancer. (Patty's 1981)

Nickel compounds vary in their carcinogenicity, but have been implicated in respiratory tract cancers in exposed industrial workers. Since several nickel compounds often occur together in industrial settings, it is difficult to attribute health effects to any single nickel compound. (ECIETC 1989) However, studies have found increased cancer risk associated with nickel oxide (Doll 1991).

Nickel and its compounds are classified as confirmed human carcinogens (ACGIH 1993-1994).

\section{Polyacrylonitrile}

Unlike its monomer, acrylonitrile, polyacrylonitrile has no recognized toxicity (Gosselin 1984; RTECS 1987). Neither IARC nor NTP has investigated the carcinogenicity of polyacrylonitrile (IARC 1992; NTP 1993).

\section{Polyethylene Glycol Acrylate}

No data were located for this compound (RTECS 1987; Sax and Lewis 1989; HSDB 1994). Neither IARC nor NTP has investigated the carcinogenicity of polyethylene glycol acrylate (IARC 1992; NTP 1993).

\section{Polyethylene Glycol Methacrylate}

No data were located for this compound (RTECS 1987; Sax and Lewis 1989; HSDB 1994). Neither IARC nor NTP has investigated the carcinogenicity of polyethylene glycol methacrylate (IARC 1992; NTP 1993).

\section{Polyethylene Oxide (synonym: polyethylene glycol)}

Toxicity is related to the molecular weight of the polyethylene glycol compound. Toxicity data are available for many of these compounds. Liquid products (MW 200 to 400) have produced toxicity, while solid products (MW 3000 or more) are largely nonabsorbed. Hepatic and kidney effects have been reported. Contact dermatitis and other skin effects have been observed. Polyethylene glycol is essentially inert when taken orally, unless very large amount of low molecular weight compounds are ingested. Ingestion of 2 liters of polyethylene glycol 400 in an adult resulted in serious toxicity (HSDB 1994). This compound is slightly toxic by ingestion, and is a skin and eye irritant in animals 
(Sax and Lewis 1989). Neither IARC nor NTP has investigated the carcinogenicity of polyethylene oxide (IARC 1992; NTP 1993).

\section{Polyphosphazene}

No data were located for this compounds (RTECS 1987; Sax and Lewis 1989; HSDB 1994). Neither IARC nor NTP has investigated the carcinogenicity of polyphosphazene (IARC 1992; NTP 1993).

\section{Polypropylene Oxide}

No data were located for this compound RTECS, 1987; Sax and Lewis 1989; HSDB 1994). Neither IARC nor NTP has investigated the carcinogenicity of polypropylene oxide (IARC 1992; NTP 1993).

\section{Polysiloxane}

Only rabbit skin and eye irritation data were located for "polysiloxane resin, 30\%" (RTECS 1987). This compound produced mild irritation of rabbit skin with application of $500 \mathrm{mg}$, and mild to moderate eye irritation in the rabbit with application of a solution containing $100 \mathrm{mg}$ polysiloxane. No additional toxicity data were located for this compound (Sax and Lewis 1989; HSDB 1994). Neither IARC nor NTP has investigated the carcinogenicity of polysiloxane (IARC 1992; NTP 1993).

\section{Polyvinylidene Fluoride}

1,1-Difluoroethylene polymer is listed as a synonym for polyvinylidene fluoride (RTECS 1987). The only toxicity data cited is an inhalation concentration at which $50 \%$ of a mouse test populations died $\left(\mathrm{LC}_{50}\right)$ of $99 \mathrm{gm} / \mathrm{m}^{3}$ for 30 minutes (RTECS 1987). No additional toxicity data were located for this compound (Sax and Lewis 1989; HSDB 1994). Neither IARC nor NTP has investigated the carcinogenicity of polyvinylidene fluoride (IARC 1992; NTP 1993).

\section{Propylene Carbonate}

This compound is mildly toxic by ingestion in laboratory animals. It is also a skin ( $100 \mathrm{mg} / \mathrm{day}$ intermittent human skin exposure) and eye irritant in laboratory animals (Sax and Lewis 1989). Inhalation of the concentrated vapor for 8 hours was not lethal to rats (Patty's 1981). No human toxicity data were located. Propylene carbonate has not been investigated by IARC or NTP for carcinogenicity (IARC 1992; NTP 1993). 


\section{Teflon® (polytetrafluoroethylene)}

There are many different CAS numbers and synonyms for Teflon (STN 1994). This toxicity summary is based on information for CAS number 9002-84-0, listed as "Teflon" in the Hazardous Substances Database. Teflon is inert under ordinary circumstances, although there have been reports of polymer fume fever in humans exposed to unfinished product. In addition, several cases of polymer fume fever have been reported when individuals smoked cigarettes contaminated with Teflon particles.

When the polymer is heated under conditions of inadequate ventilation, polymer fume fever, an influenza-like syndrome, may result. Respiratory discomfort may persist for several weeks. Pulmonary edema has been reported; this effect is more likely to be noted with exposure to fumes when Teflon is heated to temperatures of $500^{\circ} \mathrm{C}$ and greater. Some Teflon decomposition products are irritants of the eyes and mucous membranes. Different Teflon decomposition products vary widely in toxicity in experimental animals (HSDB 1994).

Experimental animals with Teflon implants beneath the skin have developed local sarcomas. One human with a Teflon surgical implant developed a local sarcoma (HSDB 1994). IARC states that, based on the available data, there is inadequate evidence of carcinogenicity in experimental animals, and no adequate data in humans (IARC 1979). IARC classifies this compound in Group 3 (IARC 1987). NTP has not investigated Teflon for carcinogenicity (NTP 1993).

\section{Tetrahydrofuran}

Human data on the toxicity of tetrahydrofuran is limited. Toxicity is expected following exposure to a $2.5 \%$ concentration. Vapors or oral ingestion may cause nausea, dizziness, headache and CNS depression. Anesthesia lasting 6 to 8 hours may occur with inhalation of high concentrations. This compound may be dermally irritating in concentrations of 20\% (HSDB 1994); since other reports contradict this, saying that tetrahydrofuran did not irritate or sensitize the skin (ACGIH 1989).

Animal studies indicate that tetrahydrofuran is only moderately toxic from acute exposure. Median lethal concentrations by inhalation varied with the duration of exposure but were greater than 20,000 $\mathrm{ppm}$ with all species for exposures of one hour or less. Animal studies showed irritation of the skin, eyes, nose and upper respiratory tract. High acute doses produced anesthesia with delayed induction and recovery periods. Other effects recorded are damage to liver, kidneys, and lung after prolonged exposures to levels of tetrahydrofuran greater than 1000 ppm (HSDB 1994).

The only report on carcinogenicity is that of a test for skin tumors in which tetrahydrofuran was applied to the skin of mice. This compound was negative when tested for mutagenicity using the Ames test. However, it appeared to enhance the mutagenicity of certain other substances (HSDB 1994). Neither IARC nor NTP has investigated the carcinogenicity of tetrahydrofuran (IARC 1992; NTP 1993). 


\section{Titanium Dioxide and Titanium Disulfide}

Titanium dioxide and titanium metal are considered toxicologically inert, because they are insoluble and unreactive. Little information is available on titanium disulfide, which, like the dioxide, is insoluble. In contrast, soluble, reactive compounds of titanium are much more harmful.

Titanium dioxide dust in industrial settings is a respiratory irritant. Tests finding no carcinogenicity supported its approval as a food additive (Patty's 1981).

\section{Vanadium Oxides}

Vanadium oxides vary in their toxicity, with vanadium pentoxide $\left(\mathrm{V}_{2} \mathrm{O}_{5}\right)$ more toxic than vanadium trioxide $\left(\mathrm{V}_{2} \mathrm{O}_{3}\right)$ (Leuschner et al. 1994). Considering acute toxicity, inhalation of vanadium pentoxide can cause death due to respiratory distress in animals. In humans, acute exposure to vanadium pentoxide dust results in coughing and respiratory irritation (Patty's 1981).

Similarly, chronic exposure to respirable vanadium pentoxide results in extensive irritation of the respiratory tract, potentially leading to bronchitis, pneumonia, and chronic respiratory disease. Other effects include eye irritation and skin disease (Patty's 1981). 


\section{Appendix B}

\section{General Conditions Governing the Classification and Transport of Lithium Batteries Under the United Nations (UN) Recommendations}

\section{(UN Special Provision 230)}

Lithium cells and batteries may be transported under this entry if they meet the following requirements:

(a) each cell contains not more than $12 \mathrm{~g}$ of lithium or lithium alloy;

(b) each battery contains not more than $500 \mathrm{~g}$ of lithium or lithium alloy;

(c) each cell and battery incorporates a safety venting device or is designed in such a manner as to preclude a violent rupture under conditions normally incident to transport;

(d) each cell and battery is equipped with an effective means of preventing external short circuits;

(e) each battery containing cells or series of cells connected in parallel is equipped with diodes to prevent reverse current flow;

(f) cells and batteries are packed in strong inner packagings, containing not more than $500 \mathrm{~g}$ or lithium or lithium alloy in each packaging;

(g) cells and batteries are packed in inner packagings in such a manner as to effectively prevent short circuits and to prevent movement which could lead to short circuits;

(h) inner packagings are packed in outer packagings meeting Packing Group II requirements. For transport by air, only metal drums (1A2 or 1B2) meeting Packing Group II requirements with gas-tight gaskets are authorized;

(i) where metal packagings are used, inner packagings are separated from each other and from the inner surfaces of the metal outer packagings by at least a $25 \mathrm{~mm}$ thickness of noncombustible cushioning material;

(j) ten cells and one battery of each type taken from production each week are subjected to extreme temperature exposure and the short circuit test procedures in Part IV of the Recommendations on the Transport of Dangerous Goods, Tests and Criteria, or, subject to approval of competent authority, equivalent tests. There should be no evidence of 
distortion, leakage or internal heating in conducting the extreme temperature exposure test procedure. In the conducting of the short circuit test procedure, if venting occurs, an open flame applied to venting fumes should not produce and explosive condition; and

(k) cells and batteries are excepted from subparagraphs (h), (i) and (j) above is they are hermetically sealed provided that, prior to the first consignment, 10 cells or 4 batteries of each type to be offered for transport are subjected in sequence to the altitude simulation, extreme temperature exposure, vibration, and shock test procedures as described in Part IV of the Recommendations on the Transport of Dangerous Goods, Tests and Criteria, or equivalent tests approved by the competent authority, with no visible evidence of outgassing, leakage, loss of mass or distortion.

(l) Cells and batteries are excepted from subparagraph (j) if they are assigned to Class 9 on the basis of tests carried out in accordance with Part IV of the Recommendations, Tests and Criteria 


\title{
Appendix C
}

\section{United Nations (UN) Recommendations: Test Methods and Criteria for Lithium Cells and Batteries}

\author{
(Section 2 of Part IV; Recommendations on \\ the Transport of Dangerous Goods - \\ Tests and Criteria)
}

\subsection{Purpose}

This section presents the procedures to be followed for the classification of lithium cells and batteries (see UN 3090 [lithium batteries] and UN 3091 [lithium batteries contained in equipment], and Special Provisions 188 and 230 in Chapter 3 of the Recommendations on the Transport of Dangerous Goods).

\section{$2.2 \quad$ General}

2.2.1 Lithium cells and batteries should be subjected to the classification procedures, as applicable, under Special Provisions 188 and 230 prior to the initial transport of a particular cell or battery type. Lithium cells or batteries which differ from a test type by:

(a) a change of more than $20 \%$ by mass to the cathode, to the anode, or to the electrolyte; or

(b) a change that would materially affect the test should results be considered a new type and should be subjected to these classification procedures. In the event that a lithium cell or battery type does not meet the test criteria in 2.4 , steps should be taken to correct the deficiency or deficiencies that caused the failure before such cell or battery type is retested.

2.2.2 For the purpose of this section:

Battery means two or more cells which are electrically connected together by a permanent means;

Cell means a single encased electrochemical unit which exhibits voltage differential across its two terminals;

Component cell means a cell contained in a battery; 
Cycle means one sequence of fully charging and fully discharging a rechargeable cell or battery;

Disassembly means a vent or rupture where solid matter from any part of a cell or battery penetrates a wire mesh screen (annealed aluminum wire with a diameter of $0.25 \mathrm{~mm}$ and grid density of 6 or 7 wires per $\mathrm{cm}$ ) placed $25 \mathrm{~cm}$ away from the cell or battery;

Effluent means a liquid or gas released when a cell or battery vents or leaks;

First cycle means the initial cycle following completion of all manufacturing processes;

Fully charged means a rechargeable cell of battery which has been electrically charged to its designed starting condition;

Fully discharged means either:

(a) a primary cell or battery which has been electrically discharged to remove $100 \%$ of its rated capacity; or

(b) a rechargeable cell or battery which has been electrically discharged to a load voltage of less than $2 / 3$ of its starting open circuit voltage;

Primary means a cell or battery which is not designed to be electrically charged or recharged;

Protective devices means devices such as fuses, diodes and current limiters which stop the current flow, block the current flow in one direction or limit the current flow in an electrical circuit;

Rated capacity means the capacity, in ampere-hours, of a cell or battery as measured by subjecting it to a load, temperature and voltage cutoff point specified by the manufacturer;

Rechargeable means a cell or battery which is designed to be electrically recharged;

Short circuit means a direct connection between positive and negative terminals of a cell or battery that provides a virtual zero resistance path for current flow;

Type means a particular electrochemical system and physical design of cells or batteries;

Undischarged means a primary cell or battery which has not been discharged; such a discharge does not include normal self-discharge resulting from reactions during storage. 
2.2.3 Under this classification procedure lithium cells and batteries are subjected to a number of test series simulating extreme conditions of transport. Each test series includes one or more test procedures. These test procedures include:

2.2.3.1 Altitude simulation: Cells and batteries are stored for at least 6 hours at an absolute pressure of $11.6 \mathrm{kPa}$ and a temperature of $20^{\circ} \mathrm{C}$;

2.2.3.2 Extreme temperature exposure: Cells and batteries are stored for at least 48 hours at a temperature of $75^{\circ} \mathrm{C}$, followed immediately by storage for at least 6 hours at a temperature of $-20^{\circ} \mathrm{C}$, followed immediately by storage for at least 24 hours at room temperature. The maximum time between storage at $75^{\circ} \mathrm{C}$ and $-20^{\circ} \mathrm{C}$ is 5 minutes;

2.2.3.3 Short circuit: At a temperature of $55^{\circ} \mathrm{C}$, cells and batteries are subjected to a short circuit current by connecting a conductor across the positive and negative terminals. Cells and batteries should remain connected to the conductor for at least 1 hour after the case temperature has returned to $55^{\circ} \mathrm{C}$;

2.2.3.4 Vibration: Cells and batteries are rigidly clamped to the platform of the vibration machine in such a manner that they are firmly held without any dimensions being altered. A simple harmonic motion having an amplitude of $0.8 \mathrm{~mm}(1.6 \mathrm{~mm}$ total excursion) is applied. The frequency is varied at a rate of $1 \mathrm{~Hz} / \mathrm{min}$ between the limits of 10 to $55 \mathrm{~Hz}$. The entire range of frequencies and return is traversed in $95 \pm 5$ minutes for each of three mutually perpendicular mounting positions of the cell or battery. Where a cell or battery has only two axes of symmetry, it is tested perpendicular to each axis. One of the directions of vibration is perpendicular to the terminal face;

2.2.3.5 Shock: Cells and batteries are secured to the shock test apparatus by means of a rigid mount which will support all mounting surfaces. Each cell and battery is subjected to three shocks of equal magnitude applied in each of three mutually perpendicular directions normal to the face of the cell or battery. In each case, the cell or battery is accelerated in such a manner that during the first 3 milliseconds the minimum average acceleration is 75 times the local acceleration due to gravity. The peak acceleration should between 125 and 175 times the local acceleration due to gravity;

2.2.3.6 Charge test: A test cell or battery is connected in a series string with undischarged primary cells or batteries or fully charged rechargeable cells or batteries of the same type in such a way that the terminals of the test cell or battery are connected in reverse. For cells with nominal voltages of less than 2 volts and batteries containing component cells with nominal voltages of less than 2 volts each, the total number of cells or batteries in the series string, including the test cell or battery, is defined by " 18 volts/ $\mathrm{V}$ ", rounded up to the nearest whole number, where $\mathrm{V}$ is the nominal voltage of one cell or battery. For cells with nominal voltages of 2 volts or greater 
and batteries containing component cells, each with nominal voltages of 2 volts or greater, the total number of cells or batteries in the series string, including the test cell or battery, is defined by " 12 volts/ $V$ ", rounded up to the nearest whole number, where $\mathrm{V}$ is the nominal voltage of one cell or battery. A resistive load is added to the series string of cells or batteries. Where the cell or battery contains no protective devices, the resistive load is such that the average current draw is the same as the maximum discharge current specified by the manufacturer. If the cell or battery contains one or more protective devices, the resistive load should be just above (by not more than $10 \%$ ) the highest resistive load at which one of those protective devices could activate during the charge test. The circuit is closed, charging the test cell or battery. The test is continued, from the time when the circuit is closed, until the voltage of the series string reaches $10 \%$ of its original open circuit voltage or for 24 hours, whichever is longer;

2.2.3.7 Internal short circuit: Each cell is deformed until the open circuit voltage drops abruptly or is reduced to at least one third. The deformation is effected by placing the rod between one jaw of the clamping device and the cell and applying force. At the point where the cell voltage drops, the applied force should be removed;

2.2.3.8 Low capacity cell: Batteries are discharged under a resistive load. Where protective devices are installed, the resistive load should be just above (by not more than $10 \%$ ) the highest resistive load at which one of these protective devices could activate during the forced discharge test. Where no protective devices are installed, the resistive load is such that, for a battery assembled with all undischarged or uncycled cells, the average current draw is the same as the maximum discharge rate specified by the manufacturer. The discharge should be terminated when the battery terminal voltage is $10 \%$ or less of the original open circuit voltage. Batteries are observed for an additional 24 hours after load removal;

2.2.3.9 Forced discharge: A test or battery is connected in a series string with undischarged primary cells or batteries or fully charged rechargeable cells or batteries of the same type. For cells with nominal voltages of less than 2 volts and batteries containing component cells with nominal voltages of less than 2 volts each, the total number of cells or batteries in the series string, including the test cell or battery, is defined by "18 volts/ $\mathrm{V}$ ", rounded up to the nearest whole number, where $\mathrm{V}$ is the nominal voltage of one cell or battery. For cells with nominal voltages of 2 volts or more and batteries containing component cells with nominal voltages of 2 volts or more, the total number of cells or batteries in the series string, including the test cell or battery, is defined by " 12 volts $/ \mathrm{V}$," rounded up to the nearest whole number. A resistive load is added to the series string of cells or batteries. Where the cell or battery contains no protective devices, the resistive load is such that the average current draw is the same as the maximum discharge current specified by the manufacturer. Where protective devices are installed, the resistive load should be just above (by not more than $10 \%$ ) the highest resistive load at which one of these protective devices could 
activate on the forced discharge test. The circuit is closed, discharging the test cell or battery. The test is continued, from the time the circuit is closed, until the voltage of the series string reaches $10 \%$ of its original open circuit voltage or 24 hours, whichever is longer.

2.2.4 Unless indicated otherwise the criteria given in 2.4 should be used for evaluating each test.

\section{Test Series}

2.3.1.

Test Series 1: Altitude simulation, extreme temperature and short circuit

2.3.1.1 Introduction: This altitude simulation, extreme temperature exposure and short circuit test is designed to determine the ability of primary and rechargeable lithium cells and batteries to withstand exposure to low pressure, high and low temperatures and external short circuits;

2.3.1.2 Apparatus and materials: The following apparatus is required for this test: a balance, a vacuum chamber, an electric oven, a freezer, a conductor with a total resistance of not more than 0.05 ohms, a thermocouple and a recording millivoltmeter.

2.3.1.3 Number and condition of cells and batteries to be tested:

Ten primary cells should be tested in both undischarged and fully discharged states.

Four primary batteries should be tested in both undischarged and fully discharged states.

Ten rechargeable cells should be tested, at first cycle, in both fully charged and fully discharged states

Four rechargeable batteries should be tested, at first cycle, in both fully charged and fully discharged states.

Ten rechargeable cells should be tested, after cycling to reduce the capacity to $60 \%$ of the rated capacity, in both fully charged and fully discharged states.

Four rechargeable batteries should be tested, after cycling to reduce the capacity to $60 \%$ of the rated capacity, in both fully charged and fully discharged states;

2.3.1.4 Each cell and battery is subjected in sequence to the test procedures described in 2.2.3.1, 2.2.3.2 and 2.2.3.3.

Test Series 2: Vibration, shock and short circuit 
2.3.2.1 Introduction: This vibration, shock and short circuit test is designed to determine the ability of primary and rechargeable lithium cells and batteries to withstand vibration, shock and external short circuits;

2.3.2.2 Apparatus and materials: The following apparatus is required for this test: a vibration machine, a shock test apparatus, a conductor with a total resistance of not more than $0.05 \mathrm{ohms}$, a thermocouple and a recording millivoltmeter;

2.3.2.3 Number and condition of cells and batteries to be tested:

Ten primary cells should be tested in both undischarged and fully discharged states.

Four primary batteries should be tested in both undischarged and fully discharged states.

Ten rechargeable cells should be tested, at first cycle, in both fully charged and fully discharged states.

Four rechargeable batteries should be tested, at first cycle, in both fully charged and fully discharged states.

Ten rechargeable cells should be tested, after cycling to reduce the capacity to $60 \%$ of the rated capacity, in both fully charged and fully discharged states.

Four rechargeable batteries should be tested, after cycling to reduce the capacity to $60 \%$ of the rated capacity, in both fully charged and fully discharged states;

2.3.2.4 Each cell and battery is subjected in sequence to the test procedures described in 2.2.3.4, 2.2.3.5 and 2.2.3.3.

\subsubsection{Test Series 3: Vibration, shock, and charge}

2.3.3.1 Introduction: A vibration, shock, and charge test is designed to determine the ability of primary and rechargeable lithium cells and batteries to withstand vibration, shock and charging. This test is applicable to all batteries with nominal voltages up to the limits indicated in 2.3.3.3.2 and 2.3.3.3.3 and to all cells;

2.3.3.2 Apparatus and materials: The following apparatus is required for this test: a vibration machine, a shock test apparatus, a resistor and a voltmeter;

2.3.3.3 Number and condition of cells and batteries to be tested:

2.3.3.3.1 Cells: 
Ten primary cells should be tested in the undischarged state.

Ten rechargeable cells should be tested, at first cycle, in the fully charged state.

Ten rechargeable cells should be tested, after cycling to reduce the capacity to $60 \%$ of the rated capacity, in the fully charged state;

2.3.3.3.2 Batteries containing component cells with a nominal voltage of less than 2 volts per component cell:

Four primary batteries with a nominal voltage of up to 6 volts should be tested in the undischarged state.

Four rechargeable batteries with a nominal voltage of up to 6 volts should be tested, at first cycle, in the fully charged state.

Four rechargeable batteries with a nominal voltage of up to 6 volts should be tested, after cycling to reduce the capacity to $60 \%$ of the rated capacity, in the fully charged state;

2.3.3.3.3 Batteries containing component cells with a nominal voltage of 2 volts or greater per component cell:

Four primary batteries with a nominal voltage of up to 4 volts should be tested in the undischarged state.

Four rechargeable batteries with a nominal voltage of up to 4 volts should be tested, at first cycle, in the fully charged state.

Four rechargeable batteries with a nominal voltage of up to 4 volts should be tested, after cycling to reduce the capacity to $60 \%$ of the rated capacity, in the fully charged state.

2.3.3.4 Each cell and battery is subjected in sequence to the test procedures described in 2.2.3.4, 2.2.3.5 and 2.2.3.6.

\subsubsection{Test Series 4: Internal short circuit}

2.3.4.1 Introduction: This internal short circuit test is designed to determine the effects of an internal short circuit in primary and rechargeable lithium cells and component cells;

2.3.4.2 Apparatus and materials: The following apparatus is required for this test: a clamping device (vice, hydraulic ram, etc.) with insulated clamping plates, a $6 \mathrm{~mm}$ 
(diameter) rod with a hard insulating surface and a voltmeter;

2.3.4.3 Number and condition of cells and batteries to be tested:

This test should be performed on single cells only. In the case of batteries, component cells of the same type as those included in the battery should be used.

Ten primary cells should be tested in the undischarged state.

Ten component cells from primary batteries should be tested in the undischarged state.

Ten rechargeable cells should be tested, at first cycle, in the fully charged state.

Ten component cells from rechargeable batteries should be tested, at first cycle, in the fully charged state;

2.3.4.4 Each cell is subjected to the test procedures described in 2.2.3.7.

\subsubsection{Test Series 5: Vibration, shock and low capacity cell}

2.3.5.1 Introduction: This vibration, shock and low capacity cell test is designed to determine the ability of primary lithium batteries, with one fully discharged cell in each series string, or rechargeable lithium batteries, with one cell cycled to $60 \%$ of its rated capacity in each series string, to withstand vibration, shock and forced deep discharge;

2.3.5.2 Apparatus and materials: The following apparatus is required for this test: a vibration machine, a shock test apparatus, a resistor and a voltmeter;

2.3.5.3 Number and condition of cells and batteries to be tested:

Primary batteries should be constructed with undischarged cells except for one in each series string which is fully discharged. Four batteries are tested in the undischarged state.

Rechargeable batteries should be constructed with uncycled cells except for one in each series string which is cycled until the capacity is reduced to $60 \%$ of the rated capacity. Four batteries are tested at first cycle in the fully charged state;

2.3.5.4 Each battery is subjected in sequence to the test procedures described in 2.2.3.4, 2.2.3.5 and 2.2.3.8.

2.3.6 Test Series 6: Forced discharge 
2.3.6.1 Introduction: This forced discharge test is designed to determine the ability of primary and rechargeable lithium cells and batteries to withstand forced deep discharge. This test is applicable to all batteries with nominal voltages up to the limits specified in 2.3.6.3.2 and 2.3.6.3.3, and to all cells;

2.3.6.2 Apparatus and materials: The following apparatus is required for this test: a resistor and voltmeter;

2.3.6.3 Number and condition of cells and batteries to be tested:

\subsection{Cells:}

Ten primary cells should be tested in the fully discharged state.

Ten rechargeable cells should be tested, at first cycle, in the fully discharged state.

Ten rechargeable cells should be tested, after cycling to reduce the capacity to $60 \%$ of the rated capacity, in the fully discharged state;

2.3.6.3.2 Batteries containing component cells with a nominal voltage of less than 2 volts per component cell.

Four primary batteries with a nominal voltage of up to 9 volts should be tested in the fully discharged state.

Four rechargeable batteries with a nominal voltage of up to 9 volts should be tested, at first cycle, in the fully discharged state.

Four rechargeable batteries with a nominal voltage of up to 9 volts should be tested, after cycling to reduce the capacity to $60 \%$ of the rated capacity, in the fully discharged state;

2.3.6.3.3 Batteries containing component cells with á nominal voltage of 2 volts or greater per component cell:

Four primary batteries with a nominal voltage of up to 6 volts should be tested in the fully discharged state.

Four rechargeable batteries with a nominal voltage of up to 6 volts should be tested, at first cycle, in the fully discharged state.

Four rechargeable batteries with a nominal voltage of up to 6 volts should be tested, after cycling to reduce the capacity to $60 \%$ of the rated capacity, in the fully discharged state. 
2.3.6.4 Each cell and battery is subjected to the test procedure described in 2.2.3.9.

\section{$2.4 \quad$ Test Criteria and Method of Assessing the Results}

2.4.1 A lithium cell or battery is of the type proved to be non-dangerous if:

(a) no disassembly or fire occurs;

(b) in the case of Test Series 1,2 and 5 unless the effluent is not toxic, flammable or corrosive:

(i) no venting or leakage is evident by visual observation; and

(ii) no venting or leakage occurs which results in a loss of mass exceeding that shown below; and

(c) in the case of Test Series 3 and 6, unless the effluent is not toxic or corrosive:

(i) no venting or leakage is evident by visual observation; and

(ii) no venting or leakage occurs which results in a loss of mass exceeding that shown below. 


\begin{tabular}{|c|c|}
\hline Mass of Cell or Battery & Maximum Mass Loss (\%) \\
\hline not more than $1 \mathrm{~g}$ & 0.5 \\
\hline more than $1 \mathrm{~g}$ but not more than $5 \mathrm{~g}$ & 0.2 \\
\hline more than $5 \mathrm{~g}$ & 0.1 \\
\hline
\end{tabular}

2.4.2 A lithium cell or battery is included in Class 9 if:

(a) no disassembly or fire occurs; and

(b) where the effluent is toxic, flammable or corrosive, a venting or leakage occurs on Test Series 1, 2 or 5:

(i) which is evident by visual observation; or

(ii) which results in a loss of mass exceeding that shown in the table in 2.4.1; or

(c) where the effluent is toxic or corrosive, a venting or leakage occurs on Test Series 3 or 6 :

(i) which is evident by visual observation; or

(ii) which results in a loss of mass exceeding that shown in 2.4.1.

2.4.3 Where a lithium cell or battery disassembles or produces a fire during the testing procedure, it may only be transported with special authorization granted by the competent authority. 


\section{Appendix D}

\section{General Conditions Governing the Transport of Lithium Batteries and Cells Under the Department of Transportation Regulations}

(49 CFR Section 173.185)

\section{$173.185 \quad$ Lithium batteries and cells}

(a) Except as otherwise provided in this subpart, lithium batteries and cells described in this section are authorized for transportation by highway, rail, vessel and cargo-only aircraft. Rechargeable lithium batteries and cells and devices containing regulated lithium batteries (including lithium batteries contained in equipment) and cells, may not be transported except as approved by the Associate Administrator for Hazardous Materials Safety.

(b) No cell may contain more than $12 \mathrm{~g}$ (0.42 ounce) of lithium or lithium alloy.

(c) Each cell and battery must be equipped with an effective means of preventing external short circuits.

(d) Each cell and battery must incorporate a safety venting device or be designed in a manner that will preclude a violent rupture when subject to an incident in transportation, such as a dead short.

(e) Batteries containing cells or series of cells connected in parallel must be equipped with diodes to prevent reverse current flow.

(f) Except as provided in paragraph (j) of this section, cells or batteries may not be offered for transportation or transported if any cell has been discharged to the extent that the open circuit voltage is less than two volts or is less than $2 / 3$ of the voltage of the fully charged cell, whichever is less.

(g) Lithium cells and batteries must be packaged in packagings conforming to the requirements of part 178 of this subchapter at the Packing Group II performance level, as follows:

(1) In strong inner fiberboard packagings containing not more than $500 \mathrm{~g}$ (17.6 ounces) of lithium or lithium alloy per inner packaging.

(2) For transportation by water, rail or highway, inner packagings must be packed within a wooden box $(4 \mathrm{Cl}, 4 \mathrm{C} 2,3 \mathrm{D}$ or $4 \mathrm{~F})$, fiberboard box $(4 \mathrm{G})$, fiber drum ( $1 \mathrm{G})$, or metal drum $(1 \mathrm{~A} 2$ or $1 \mathrm{~B} 2)$. 
(3) Except as provided in paragraph (h)(3) of this section, for transportation by cargoonly aircraft, the inner packaging must be packed in a steel drum (1A2) with a gas tight gasket. The maximum gross weight of the package must not exceed $35 \mathrm{~kg}$ (77 pounds).

(4) When the outer packaging is a metal drum, inner packagings must be separated from each other and from the outer packaging by at least $25 \mathrm{~mm}$ (1 inch) of noncombustible cushioning material.

(h) Lithium batteries and cells must be tested as follows:

(1) The cell or battery must be subjected to a thermal stability test at $75^{\circ} \mathrm{C}\left(167^{\circ} \mathrm{F}\right)$ for 48 hours and must show no evidence of distortion, leakage or internal heating. This test must be performed on at least 10 cells and 1 battery of each type taken from each week's production, or as otherwise approved by the Associate Administrator for Hazardous Materials Safety.

(2) Under application of a direct short, the cell or battery must be rendered inert, preferably without venting (through the use of internal fusing devices). If venting does occur, an open flame must be applied to the venting fumes to prove than an explosive condition does not exist. This test must be performed on at least 3 cells and 1 battery of each type taken from each week's production, or as otherwise approved by the Associate Administrator for Hazardous Materials Safety.

(3) Cells containing no more than $12 \mathrm{~g}$ (0.42 ounce) of lithium metal which are hermetically sealed, and batteries constructed of such cells, are excepted from the tests in paragraphs $(\mathrm{h})(1)$ and (2) of this section and the requirement to use a 1A2 steel drum for transportation by cargo aircraft only as an outer packaging provided that:

(i) The outer packaging conforms to paragraph (g)(2) of this section; and

(ii) Prior to the first shipment, 10 cells or 4 batteries of each type to be offered for transportation, or as otherwise approved by the Associate Administrator for Hazardous Materials Safety must be tested as follows, without showing any evidence of out-gassing, leakage, loss of weight or distortion:

(A) The cells or batteries must be stored for 6 hours at an absolute pressure of $11.6 \mathrm{kPa}(1.68 \mathrm{psi})$ and a temperature of $24^{\circ} \mathrm{C} \pm 4^{\circ} \mathrm{C}$ $\left(75^{\circ} \mathrm{F} \pm 7^{\circ} \mathrm{F}\right)$.

(B) The cells or batteries must then be subjected to the thermal stability test at $75^{\circ} \mathrm{C}\left(167^{\circ} \mathrm{F}\right)$ for 48 hours as required in paragraph $(\mathrm{h})(1)$ of this section; 
(C) The cells or batteries must be rigidly clamped to the platform or a vibration machine. A simple harmonic motion having an amplitude of $0.7 \mathrm{~mm}$ ( 0.03 inch $)(1.4 \mathrm{~mm}$ ( $0.06 \mathrm{inch})$ maximum total excursion) must be applied. The frequency must be varied at the rate of $1 \mathrm{~Hz} /$ min between the limits of $10 \mathrm{~Hz}$ to $55 \mathrm{~Hz}$. The entire range of frequencies and return must be traversed in $95 \pm 5$ minutes for each of three mutually perpendicular mounting positions of the cells. One of the directions of vibration must be perpendicular to the terminal face of the battery or cell. Open circuit voltage must be observed for 30 seconds during the last quarter of each vibration period. Periodic retesting is not required;

(D) The battery must be secured to a shock testing machine by means of a rigid mount which will support all mounting surfaces of the battery. Each battery must be subjected to a total of three shocks of equal magnitude. The shocks must be applied in each of three mutually perpendicular directions. Each shock must be applied in a direction normal to a face of the battery. For each shock, the battery must accelerated in such a manner that during the first 3 milliseconds the minimum average acceleration is $75 \mathrm{~g}$ (where $\mathrm{g}$ is the local acceleration due to gravity). The peak acceleration must be between $125 \mathrm{~g}$ and $175 \mathrm{~g}$.

(i) Lithium batteries and cells, rechargeable lithium batteries and cells, and devices containing lithium batteries and cells, are not subject to this subchapter, if they meet the following requirements:

(1) Each cell with a liquid cathode may contain no more than $0.5 \mathrm{~g}$ (0.02 ounce) of lithium or lithium alloy, and each cell with a solid cathode may contain no more than $1.0 \mathrm{~g}(0.04$ ounce $)$ lithium or lithium alloy.

(2) Each battery with a solid cathode may contain an aggregate quantity of no more than $2.0 \mathrm{~g}(0.07$ ounce $)$ of lithium or lithium alloy, and each battery with a liquid cathode may contain an aggregate quantity of no more than $1.0 \mathrm{~g}$ ( 0.04 ounce) lithium or lithium alloy.

(3) Each cell must be hermetically sealed.

(4) Cells must be separated so as to prevent short circuits.

(5) Batteries must be separated so as to prevent short circuits and must be packed in strong packagings, except when installed in electronic devices.

(6) If a liquid cathode battery contains more than $0.5 \mathrm{~g}$ ( 0.02 ounce) of lithium or lithium 
alloy or a solid cathode battery contains more than $1.0 \mathrm{~g}$ ( 0.04 ounce) lithium or lithium alloy, it may not contain a liquid or gas that is a hazardous material according to this subchapter unless the liquid or gas, if free, would be completely absorbed or neutralized by other materials in the battery.

(j) Lithium cells and batteries, for disposal, may be offered for transportation or transported to a permitted storage facility and disposal site by motor vehicle only, if the cells and batteries-

(1) When new, contained not more than $12.0 \mathrm{~g}$ (0.42 ounces) of lithium or lithium alloy per cell;

(2) Are equipped with an effective means of preventing external short circuits; and

(3) Are packed in a strong outer packaging conforming to the requirements of $\S \S$ 173.24 and 173.24a. The packaging need not conform to performance requirements of part 178 of this subchapter.

(k) Cells or batteries discharged to below 2 volts, not to exceed 100 cells or batteries per shipment, may be shipped for testing purposes by highway only.

(1) Lithium sulfur dioxide cells and batteries, for disposal, are not subject to the requirements for lithium batteries found in this subchapter under the following conditions:

(1) When new, each cell is electrochemically balanced with a ration of lithium to sulfur dioxide of $1.0 \pm 0.1$;

(2) Each battery is composed of not more than 10 cells;

(3) Each battery is discharged with a discharge device to less than $0.5 \mathrm{~g}$ (0.02 ounces) of lithium or lithium alloy per cell after complete discharge. The device must be able to completely discharge the battery in 5 days; and

(4) After being activated for discharge, the batteries are held not less than 5 days before being offered for transportation.

(m) Lithium batteries and cells which do not comply with the provisions of this section may be transported only if they are approved by the Associate Administrator for Hazardous Materials Safety. 


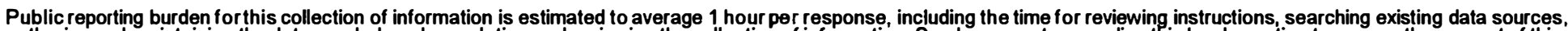

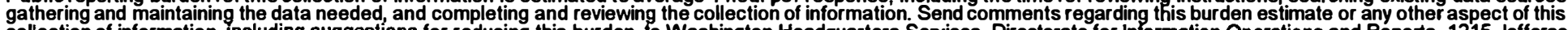

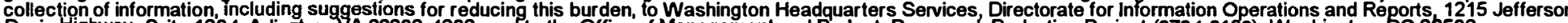

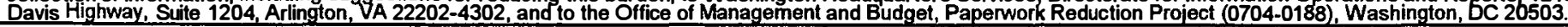
1. AGENCY USE ONLY (Leave blank)
2.REPORT
3. REPORT TYPE AND DATES COVERED
DATE. technical report
February 1995

4. TITLE AND SUBTITLE Current Status of Environmental, Health, and Safety Issues of Lithium Polymer Electric Vehicle

5. FUNDING NUMBERS Batteries AS051440

6. AUTHOR(S)

D. Corbus and C. Hammel

National Renewable Energy Laboratory

1617 Cole Boulevard

Golden, Colorado 80401-3393

8. PERFORMING ORGANIZATION REPORT NUMBER

TP-463-7540

9. SPONSORING/MONITORING AGENCY NAME(S) AND ADDRESS(ES)

U.S. Department of Energy

1000 Independence Ave., SW

Washington, DC 20585

10. SPONSORING/MONITORING AGENCY REPORT NUMBER

11. SUPPLEMENTARY NOTES

12a. DISTRIBUTION/AVAILABILITY STATEMENT National Technical Information Service U.S. Department of Commerce

5285 Port Royal Road

Springfield, VA 22161 12b. DISTRIBUTION CODE UC 1501

13. ABSTRACT (Maximum 200 words)

This report examines the potential environmental, health, and safety (EH\&S) issues associated with using solid lithium polymer (SPE) batteries as an energy source for electric vehicles. It is anticipated that SPE batteries will be safer than lithium batteries without SPEs because SPEs could eliminate some of the problems encountered in organic liquid electrolyte designs, such as a reaction with the lithium negative electrode, gas venting, and the need for sophisticated seals to contain liquids. The study assesses five issues: cell and battery safety, toxicity of lithium SPE battery materials, workplace health and safety, recycling and reclamation, and shipping of SPE batteries. In general, findings indicated that SPE cells and batteries could be designed so that they present few EH\&S risks.

14. SUBJECT TERMS solid polymer lithium battery; electric vehicle battery; lithium; environmental, health, and safety

15. NUMBER OF PAGES

78

16. PRICE CODE

20. LIMITATION OF ABSTRACT

UL
19. SECURITY CLASSIFICATION OF ABSTRACT unclassified

\section{OF REPORT}

unclassified
18. SECURITY CLASSIFICATION unclassified
Standard Form 298 (Rev. 2-89)

Prescribed by ANSI Std Z39-18 